Lasse Bork, Hans Dewachter \& Romain Houssa

Identification of Macroeconomic Factors in Large Panels

Finance

Research Group 


\title{
Identification of Macroeconomic Factors in Large Panels*
}

\author{
Lasse Bork $\rceil^{\dagger}$ Hans Dewachter ${ }^{\ddagger}$ and Romain Houssa ${ }^{\S}$
}

Current Version: September, 2009

First Draft: May 2008

\begin{abstract}
This paper presents a dynamic factor model in which the extracted factors and shocks are given a clear economic interpretation. The economic interpretation of the factors is obtained by means of a set of overidentifying loading restrictions, while the structural shocks are estimated following standard practices in the SVAR literature. Estimators based on the EM algorithm are developped. We apply this framework to a large panel of US monthly macroeconomic series. In particular, we identify nine macroeconomic factors and discuss the economic impact of monetary policy stocks. The results are theoretically plausible and in line with other findings in the literature.
\end{abstract}

JEL classifications: E3, E43, C51, E52, C33

Keywords: Monetary policy, Business Cycles, Factor Models, EM Algorithm.

*Please address any comments to romain.houssa@fundp.ac.be. We thank Tom Engsted and Priscilla Toffano for helpful comments and suggestions. We also thank Jean Boivin for kindly making the data set available on his website, HEC-Montréal. Hans Dewachter acknowledges financial support from FWO grant $\mathrm{N}^{\circ} \mathrm{G} .0626 .07$.

${ }^{\dagger}$ Finance Research Group, Aarhus School of Business, University of Aarhus and CREATES at the University of Aarhus, a research center funded by Danish National Research Foundation.

${ }^{\ddagger}$ CES, University of Leuven, RSM Rotterdam and CESIFO.

${ }^{\S}$ CRED and CEREFIM, University of Namur, CES, University of Leuven. 


\section{Introduction}

In recent years, factor models have become a standard tool in applied macroeconomics and finance. In empirical macroeconomics they have been used for predictions (Bernanke \& Boivin (2003), Forni et al. (2005), and Stock \& Watson $(2002 a, b))$; for structural analysis (Forni \& Reichlin (1998), Forni et al. (2008), Giannone et al. (2004, 2002), Houssa (2008a), Bernanke et al. (2005) and Stock \& Watson (2005)); and for constructing business cycle indicators (Forni et al. (2001), Kose et al. (2003), Houssa (2008b), and Otrok \& Whiteman (1998)). Applications of factor models in finance include the arbitrage pricing theory (Chamberlain \& Rothschild (1983) and Ingersoll (1984)); the measurement of risks (Campbell et al. (1997, ch. 2)); the estimation of the conditional risk-return relation in Ludvigson \& Ng (2007); bond market applications (Mönch (2008), Ludvigson \& $\mathrm{Ng}$ (2008) and Diebold et al. (2008)); and the prediction of the volatility of asset returns (Alessi et al. (2007)).

The increasing popularity of dynamic factor models (DFM) can be explained by two model features. First, factor models distinguish measurement errors and other idiosyncratic (series-specific) disturbances from structural shocks. As such, (dynamic) factor models provide a direct mapping from observed data to their theoretical and structural counterparts ${ }^{1}$. Second, large data sets are becoming increasingly available and classical multivariate regression models generally perform poorly in fitting them. By contrast, DFMs, exploiting the dynamic and cross-sectional structure of the panel, extract a (small) set of underlying factors. Moreover, various estimation techniques to analyze factor models in large panels have been recently developed. For instance, Stock \& Watson $(2002 a, b)$ and Forni et al. (2000) propose a non-parametric estimation approach based on principal components. The former use the time domain method while the latter suggest a frequency domain estimation technique. In a related literature, Otrok \& Whiteman (1998) and Kim \& Nelson (1999) propose a Bayesian estimation technique whereas Doz et al. (2006, 2007) and Jungbacker \& Koopman (2008) use an estimation approach based on the EM algorithm.

\footnotetext{
${ }^{1}$ Typically, these theoretical counterparts are defined within a DSGE model (see for example Altug (1989), Sargent (1989) and, recently, Boivin \& Giannoni (2006)).
} 
While these studies have provided important contributions to the literature on factor models, some identification issues remain, however. In particular, it is often the case that the (static) factors estimated in applied work do not necessarily have a well-defined and unambiguous economic interpretation ${ }^{2}$. A standard procedure amounts to inferring the economic interpretation of the factors from the dominant factor loadings. This approach, however, neglects the non-dominant (but possibly significant) loadings and hence does not necessarily generate unambiguous and well-defined interpretations of the factors.

In this paper we address this identification problem by using a procedure that imposes a specific and well-defined interpretation on the static factors. The economic interpretation of the extracted static factors is based on a set of overidentifying restrictions on factor loadings ${ }^{3}$. Furthermore, a set of standard exclusion restrictions on the impact matrix is used to identify the structural shocks. We employ the iterative maximum likelihood estimation approach as in Doz et al. (2006, 2007) and Jungbacker \& Koopman (2008). The method combines the Kalman smoother and the EM algorithm.

We illustrate our approach by revisiting the large cross-section data analyzed in Bernanke et al. (2005). We aim at identifying and extracting from the data panel nine macroeconomic factors, respectively related to inflation, unemployment, economic activity, consumption, state of the business cycle, residential investments, financial markets and monetary policy. Given the identification of these factors, we assess and analyze (as in Bernanke et al. (2005)) the impact of monetary policy shocks on a number of key macroeconomic observables through impulse response analysis and variance decompositions.

Our paper is closely related to a number of recent studies. Boivin et al. (2009) and Reis \& Watson (2008) impose loadings restrictions to identify a measure of

\footnotetext{
${ }^{2}$ Static factors are related to the variance-covariance matrix of the data while dynamic factors capture the property of their spectral density matrix. See Forni et al. (2000) for a literature review. Recent studies provide a structural interpretation to dynamic factors (shocks), see for example Giannone et al. (2004); Houssa (2008a) and Forni et al. (2008). The main difference between these studies and ours is that we identify (in economic and structural terms respectively) the static and dynamic factors.

${ }^{3}$ Alternative types of identification schemes in DFMs, among which exclusion restrictions and loading restrictions, are discussed in the literature; see for instance Stock \& Watson (2005), Reis \& Watson (2008), Forni \& Reichlin (2001) and Kose et al. (2003).
} 
pure inflation for the US economy. In the same way, Forni \& Reichlin (2001) and Kose et al. (2003) use loading restrictions to differentiate between world, regional and country factors. Finally, Boivin \& Giannoni (2006) employ loading restrictions to estimate the theoretical concepts of variables defined in DSGE model. The main difference between these studies and ours is that we employ the EM algorithm to derive closed form solutions for (linearly) restricted factor loadings. As such, we can combine various loading restrictions allowing to obtain a clear macroeconomic interpretation of the extracted factors (see sections 2 and $3)$.

The remainder of the paper is organized as follows. First, the methodological approach is explained in Section 2. We introduce a dynamic factor model and discuss the identification restrictions. In addition, closed-form solutions for the parameter estimates, consistent with the identification schemes and using results from Shumway \& Stoffer (1982) and Wu et al. (1996), are presented. An empirical illustration is provided in Section 3. Section 4 concludes.

\section{Methodology}

We first introduce the DFM. More details can be found in Forni et al. (2000) and Forni \& Lippi (2001). Subsequently, we employ the quasi maximum likelihood estimation approach as in Doz et al. $(2006,2007)$ and Jungbacker \& Koopman (2008). We take this approach one step further by imposing (over-) identifying restrictions on the loadings and on the impulse response function (IRF). This allows a clear economic interpretation of the static factors and a structural identification of the shocks.

\subsection{Dynamic Factor Model}

Consider a panel of observable economic variables $y_{i, t}$, where $i$ denotes the crosssection unit, $i=1, \ldots, N$ while $t$ refers to the time index, $t=1, \ldots, T$. The panel of observed economic variables is transformed into stationary variables with zero 
mean and unit variance. These transformed variables are labeled by $x_{i, t}$. Dynamic factor models assume that a variable $x_{i, t}$ can be decomposed into two components, the common component, $\chi_{i, t}$, and the idiosyncratic component $\xi_{i t}$ :

$$
x_{i, t}=\chi_{i, t}+\xi_{i, t}
$$

Furthermore, in exact dynamic factor models it is assumed that the idiosyncratic and common components are uncorrelated at all leads and lags and across all variables, $E\left(\xi_{i, t} \chi_{j, s}\right)=0, \forall s, t, i, j$. The common component, $\chi_{i, t}$, is assumed to be driven by a small number $r, r<<N$, of common factors $f_{t}=\left(f_{1, t} f_{2, t}, \cdots, f_{r, t}\right)^{\prime}$ :

$$
x_{i, t}=\lambda_{i} f_{t}+\xi_{i, t}
$$

where $\lambda_{i}$ is a $1 \times r$ vector of factor loadings measuring the exposure of $x_{i, t}$ to the factors $f_{t}$. The idiosyncratic component, $\xi_{i, t}$, is driven by variable-specific noise. Stacking equation (2) over all cross-section units, $x_{i, t}, i=1, \ldots, N$, gives:

$$
X_{t}=\lambda f_{t}+\xi_{t}
$$

where $X_{t}=\left(x_{1, t}, \ldots, x_{N, t}\right)^{\prime}, \xi_{t}=\left(\xi_{1, t}, \ldots, \xi_{N, t}\right)^{\prime}$, and $\lambda$ is a $N \times r$ matrix of factor loadings, $\lambda=\left(\lambda_{1}, \ldots, \lambda_{N}\right)^{\prime}$. Equation (3) is called a static factor model (see for example Forni et al. (2000) and Stock \& Watson (2002b)).

To close the model, factor dynamics have to be specified. We assume that the $r$-dimensional vector of common factors $f_{t}$ has a $\operatorname{VAR}(p)$ representation:

$$
\phi(L) f_{t}=\eta_{t}
$$

where $\phi(L)=I-\phi_{1} L-\phi_{2} L^{2}-\ldots-\phi_{p} L^{p}$, with $\phi_{j}$ denoting a $r \times r$ matrix of autoregressive coefficients $(j=1, \ldots, p)$. Moreover, given the stationarity of the transformed panel, we impose stationarity on the DFM by requiring that the 
modulus of the roots of $\phi(L)^{-1}$ lie outside the unit circle. The $q$-dimensional vector of dynamic factor innovations is denoted $\eta_{t}$. As in Doz et al. (2006), we make additional distributional assumptions: $\eta_{t} \sim$ i.i.d $N(0, Q)$ and $\xi_{t} \sim$ i.i.d $N(0, R)$, with $Q$ and $R$ denoting (semi-) positive definite matrices ${ }^{4}$.

Using equations (3) and (4), the model can be summarized in first order, with a $r p \times 1$ state vector $F_{t}, F_{t}=\left(f_{t}, \ldots, f_{t-p+1}\right)^{\prime}$, by the measurement equation:

$$
X_{t}=\Lambda F_{t}+\xi_{t}
$$

and the transition equation:

$$
F_{t}=\Phi F_{t-1}+V S u_{t}
$$

where $\Lambda$ is the $N \times r p$ matrix loading, implied by $\lambda$, $\Phi$ is the $r p \times r p$ companion matrix corresponding to $\phi(L), V=\left(I^{\prime}, 0_{r(p-1) \times q}^{\prime}\right)^{\prime}$, and $u_{t}$ represents the structural shocks that are identified through the matrix $S$ (see sub-section 2.2.2 below). Inverting the VAR in (6) and substituting $F_{t}$ in (5) gives

$$
X_{t}=B(L) u_{t}+\xi_{t},
$$

where $B(L)=\Lambda(I-\Phi L)^{-1} V S$, represents the IRF to $u_{t}$.

The state-space system, defined by equations (5) and (6), is not uniquely identified. We address the econometric identification as well as the economic interpretation of the static factors in section 2.2.1. Finally, the identification of the structural shocks $u_{t}$ is discussed in section 2.2.2.

\footnotetext{
${ }^{4}$ Note that, by assuming i.i.d idiosyncratic components, (3)-(4) define an exact DFM as opposed to an approximate factor model where some correlation is allowed among idiosyncratic components. An exact factor structure is certainly a strong assumption, particularly in the case of large panel data sets where cross-sectional and serial correlations are expected to be found. As such, (3)-(4) represent a missspecified model. However, Doz et al. (2006) show that, for large $N$ and $T$ the exact factor model estimators are consistent quasi-maximum likelihood estimators for the approximate factor model.
} 


\subsection{Economic interpretation}

Economic interpretation of the factors and shocks requires additional identification restrictions. We use two types of restrictions: $(I)$ loading restrictions allowing for a clear macroeconomic interpretation of the (static) factors, and (II) restrictions on the impact matrix identifying the structural shocks.

\subsubsection{Economic factors}

We impose a set of restrictions on the loading matrix $\Lambda$, (equation (5)), and denote the restricted loading matrix by $\Lambda^{*}$. The linear loading restrictions take the following general form:

$$
H_{\Lambda} \operatorname{vec}\left(\Lambda^{*}\right)=\kappa_{\Lambda}
$$

where $\kappa_{\Lambda}$ refers to a $\ell \times 1$ vector of $\ell$ linear combinations of restrictions of factor loadings defined by $H_{\Lambda}, H_{\Lambda} \in \mathbb{R}^{\ell \times N r}$.

We use three types of loading restrictions, depending on the information content of the observables. In particular, economic identification is achieved by means of (i) unbiasedness restrictions (ii) one-to-one restrictions or (iii) exclusion restrictions. $^{5}$ The unbiasedness restriction implies that observable $x_{j}$ is an unbiased and direct information variable for factor $f_{l}, l=1,2, \ldots, r$, :

$$
\Lambda_{j, l}^{*}=1, \Lambda_{j, k \neq l}^{*}=0 .
$$

This type of restrictions is used on observables that are assumed to be a direct measure (up to some measurement error) of the underlying factor. For instance, our empirical application assumes that the observable "CPI- $u$ all items" inflation is a direct measure for the inflation factor. As such, the unbiasedness restrictions imply a unit loading of "CPI-u all items" inflation on the inflation factor and zero loadings on all other factors. Note that these unbiasedness restrictions allow for the econometric identification of the DFM as the static factors are now uniquely

\footnotetext{
${ }^{5}$ To conform to the static factor structure of the model, all loadings on lagged factors are set to zero.
} 
defined.

The one-to-one restriction implies a one-to-one link between an observable and a factor. Unlike unbiasedness restrictions, we allow other common factors to affect the observable as well, i.e. we do not impose $\Lambda_{j, k \neq l}^{*}=0$. Formally, one-to one restrictions between observable $x_{j}$ and factor $l$ are ensured by imposing:

$$
\Lambda_{j, l}^{*}=1
$$

Finally, contemporaneous exclusion restrictions, i.e. the case where variable $x_{j}$ is (contemporaneously) not related to the factor $f_{l}$, take the form of:

$$
\Lambda_{j, l}^{*}=0 .
$$

Note that this identification scheme formalizes and extends the standard informal identification procedures used in the literature. The standard approach identifies the factors from the principal factor loadings of the economic variables, disregarding the smaller loadings. Our identification procedure formalizes this approach by (i) imposing exclusion restrictions on the non-informative variables, which ensures that only information of relevant variables is incorporated in the factor and (ii) facilitating interpretation of the factors by means of the unbiasedness or one-to-one restrictions imposing a direct mapping between the observables and the static factor.

The economic interpretation of the factors is obtained by imposing at least one unbiasedness or a one-to-one restriction per factor. However, while exclusion and unbiasedness restrictions exclude some observables from the information set of a factor, we allow for feedback effects across factors. Specifically, through the VAR specification (equation (6)), we allow for dynamic interactions among factors. As such, factors can be correlated and structural shocks are eventually transmitted across all observables. 


\subsubsection{Structural shocks}

In equation (7), structural shocks are identified. We follow the standard identification procedure in the SVAR literature by choosing an appropriate matrix $S$ such that the implied restricted IRF, $B(L)^{*}$, has an economic justification. For instance, the Blanchard \& Quah (1989) long-run restrictions can be obtained by choosing $S$ such that appropriate elements of $B(1)^{*}$ are equal zero. Sign restrictions, recently introduced by Uhlig (2005), can also be fulfilled by choosing $S$ such that the time path of some elements of $B(L)^{*}$ have an appropriate sign. Popular sign restrictions include the fact that prices cannot increase following a negative demand shock. Finally, structural identification can be obtained by imposing the Sims (1980)'s triangular representation on the matrix $S$. This is the approach followed in our empirical application in section 3. We first impose that the number of static factors equals the number of dynamic factors, i.e. $q=r$. This generates a structural shock to each of the static factors. Thereafter, we use the exclusion restrictions implied by the Cholesky decomposition of $Q=S S^{\prime}$, with $S$ lower triangular. The structural interpretation of the shocks is then implied by the ordering of the static factors and discussed in more detailed in section 3 .

\subsection{Estimation: the EM algorithm}

Given the latent nature of the static factors, a standard EM algorithm is used to estimate the parameters and to extract the implied factors. Denote by $\Theta=$ $\left\{\Lambda^{*}, R, \Phi, Q\right\}$ the set of parameters to be estimated with $\Lambda^{*}$ satisfying the set of identification restrictions listed in equation (8). Conditional on the estimates of the factors, $\hat{F}$ (and matrices measuring uncertainty $\hat{P}$ ), the elements of $\Theta$ can be 
estimated by (aaimization step):

$$
\begin{aligned}
& \operatorname{vec}\left(\Lambda^{*}\right)=\operatorname{vec}\left(D C^{-1}\right) \\
& \quad+\left(C^{-1} \otimes R\right) H_{\Lambda}^{\prime}\left[H_{\Lambda}\left(C^{-1} \otimes R\right) H_{\Lambda}^{\prime}\right]^{-1}\left\{\kappa_{\Lambda}-H_{\Lambda} \operatorname{vec}\left(D C^{-1}\right)\right\}, \\
& R=\frac{1}{T} G, \\
& \operatorname{vec}(\Phi)=\operatorname{vec}\left(B A^{-1}\right), \\
& \Omega=V Q V^{\prime}=\frac{1}{T}\left[C-B A^{-1} B^{\prime}\right],
\end{aligned}
$$

where the estimator for $\Lambda^{*}$ follows from extending results in $\mathrm{Wu}$ et al. (1996). ${ }^{6}$

Conditional on the estimated parameters, $\Theta$, the latent factors can be extracted by means of the Kalman smoother and the required moments can be computed (Expectation step). In particular, the following expectations are generated:

$$
\begin{aligned}
& A=\sum_{t=1}^{T}\left(\hat{P}_{t-1 \mid T}+\hat{F}_{t-1 \mid T} \hat{F}_{t-1 \mid T}^{\prime}\right), \\
& B=\sum_{t=1}^{T}\left(\hat{F}_{t \mid T} \hat{F}_{t-1 \mid T}^{\prime}+\hat{P}_{\{t, t-1\} \mid T}\right), \\
& C=\sum_{t=1}^{T}\left(\hat{F}_{t \mid T} \hat{F}_{t \mid T}^{\prime}+\hat{P}_{t \mid T}\right), \\
& D=\sum_{t=1}^{T} X_{t} \hat{F}_{t \mid T}^{\prime}, \\
& G=\sum_{t=1}^{T}\left(X_{t}-\Lambda^{*} \hat{F}_{t \mid T}\right)\left(X_{t}-\Lambda^{*} \hat{F}_{t \mid T}\right)^{\prime}+\Lambda^{*} \hat{P}_{t \mid T} \Lambda^{* \prime},
\end{aligned}
$$

with:

$$
\begin{aligned}
& \hat{F}_{t \mid T}=E\left(F_{t} \mid \mathcal{X}_{T}\right), \\
& \hat{P}_{t \mid T}=E\left(\left(F_{t}-\hat{F}_{t \mid T}\right)\left(F_{t}-\hat{F}_{t \mid T}\right)^{\prime} \mid \mathcal{X}_{T}\right), \\
& \hat{P}_{\{t, t-1\} \mid T}=E\left(\left(F_{t}-\hat{F}_{t \mid T}\right)\left(F_{t-1}-\hat{F}_{t-1 \mid T}\right)^{\prime} \mid \mathcal{X}_{T}\right),
\end{aligned}
$$

\footnotetext{
${ }^{6} \mathrm{~A}$ derivation of the estimator is available on request.
} 
where $E(\cdot \mid \cdot)$ denotes the conditional expectations operator implied by the Kalman smoother (as a function of $\Theta$ ), see for instance de Jong \& Mackinnon (1988) and de Jong (1989). $\mathcal{X}_{T}=\left\{X_{1}, \ldots, X_{t}\right\}$ denotes the information set. We iterate sequentially over the M-step in equation (12) and the E-step in equation (13) until convergence of the likelihood starting from different sets of initial values. $^{7}$

In our empirical application discussed in section 3 the unrestricted model involves 1,614 parameters to be estimated. This is computationally feasible with the EM algorithm method. Doz et al. (2006) suggest to initialize the Kalman filter by the parameters implied by principal components and then filter the factors. However, principal component analysis results in orthogonal factors and we prefer correlated factors $^{8}$. Consequently, we suggest to entertain an oblique rotation of the orthogonal factors which is a common tool in confirmatory factor analysis as described in Lawley \& Maxwell (1971). This approach does not change the initial fit but rotates the factors towards a target loading matrix which we choose to be the exactly identifying loading restrictions. The result is a set of correlated factors from which a set of implied initial parameters consistent with the identifying loading restrictions can be derived.

\section{Empirical Application}

We illustrate our procedure by revisiting the large data panel analyzed in Bernanke et al. (2005). This data set captures the dynamics of a wide range of macroeconomic developments in the US economy over the last decades. In particular, the sample consists of 120 time series (monthly frequency) over the period 1959:1 to 2001: $8^{9}$. The main focus of our empirical analysis is to extract a number of factors

\footnotetext{
${ }^{7}$ We define convergence using a relative tolerance of $10^{-8}$ for the log-likelihood.

${ }^{8}$ The Geweke \& Singleton (1981) identification scheme allows the factors to be correlated which is relevant if any macroeconomic interpretation is going to be attached to these factors.

${ }^{9}$ The data are already transformed by Bernanke et al. (2005) to reach stationarity; see Bernanke et al. (2005) for details on the data set and on the transformations. The final data set used contains 120 series and $T=511$ monthly observations per series. Prior to the estimation, we de-mean the series and divide them by their standard deviation such that the resulting series have zeros mean and unit variance.
} 
with an unambiguous (macro) economic interpretation. Moreover, we analyze the economic impact of monetary policy shocks on the US economy. We first discuss the identification of the factors. Subsequently, we analyze the extracted factors and finally, we use impulse response functions (IRFs) and variance decompositions to study the impact of monetary policy shocks on the US economy.

\subsection{Identification}

The identification proceeds in two steps. First, we select the number of static (and dynamic) factors, $r(q)$, and the number of lags in the VAR of the static factors. Subsequently, restrictions are imposed to identify and interpret in macroeconomic terms the static factors and structural shocks.

\subsubsection{Number of factors}

Our preferred specification contains nine factors and includes six lags in the dynamics of the factors $(\widehat{r}=\widehat{q}=9$ and $\widehat{p}=6)$. The number of dynamic factors is relatively high compared to the literature. For example, Giannone et al. (2004) argue that the number of shocks (dynamic factors) driving the US economy is equal to two (i.e. $\widehat{q}=2$ ). Stock \& Watson (2005) analyzing the same data set, but with a different method, argue that seven dynamic factors and nine static factors are required ( $\widehat{q}=7$ and $\widehat{r}=9$ ). Bai \& Ng (2007) and Hallin \& Liska (2007) opt for $\widehat{q}=4$. Bernanke et al. (2005), analyzing another large US panel, prefer a model specification with four factors $(\widehat{r}=\widehat{q}=4)$. Bork (2008) considers the same data as in Bernanke et al. (2005) and based on various information criteria finds that an exactly identified factor-augmented VAR model with $\hat{r}=8$ explains the data well.

Part of the reported difference in the number of factors can be attributed to the fact that earlier research focussed primarily on fitting the leading statistical indicators for economic activity and inflation. As demonstrated by Stock \& Watson (2005), additional factors are required to fit the other dimensions of the data panel. We follow this line of reasoning and allow for two additional factors rel- 
ative to their seven dynamic factors. The motivation for introducing two more factors is based on the observation that our approach, unlike the latent factor approach, imposes a large number of overidentifying restrictions on the loading matrix. These over-identifying restrictions most likely reduce the flexibility and the fit of the factor model. This decrease in flexibility is compensated for by increasing the number of factors. The statistical performance of this restricted nine-factor model is discussed in section 3.2. Before, we provide economic identification of factors and shocks in the next sub-section.

\subsubsection{Economic interpretation of factors and shocks}

We identify the nine retained static factors using a relatively wide array of economic concepts or interpretations, relevant for empirical monetary policy analysis. The identification of seven out of the nine factors is motivated by small-scale macroeconomic theoretical models. Our identification procedure is also based on empirical findings in Stock \& Watson (2005). In particular, we retain four (aggregate supply) factors: an inflation factor $(\pi)$; an economic activity factor $(y)$; an hours in production factor (hrs) functioning as a buffer to changes in demand and an unemployment factor $\left(u_{n}\right)$. The standard aggregate demand equation motivates the identification of the following three factors: a consumption factor $(c)$; a housing factor $(h)$ approximating (residential) investment; and a monetary policy factor $(i)^{10}$.

The remaining two factors have an interpretation either as additional information factors or as financial factors. ${ }^{11}$ More precisely, we identify a stock market factor $(s)$ capturing wealth or information effects and a commodity price factor (pcom)

\footnotetext{
${ }^{10}$ For more details we refer to Bernanke et al. (2005) for a nice exposition on the mapping between a small-scale macro model and a factor model.

${ }^{11}$ Information variables (or information factors) are assumed to be monitored by central banks because they may display relevant information that is not available in typical macroeconomic variables. See Leeper et al. (1996), Christiano et al. (1999) and very recently Bjørnland \& Leitemo (2009) for a discussion. Generally, information variables are fast-moving variables that respond contemporaneously to all variables. Examples of fast moving variables include auction market commodity prices, stock prices, and options on financial instruments.
} 
capturing information on nascent inflation pressures.

\section{Insert Table 1}

Table 1 offers an overview of the identification restrictions. The identification of the respective factors is obtained in two steps. First, we fix the interpretation of the factors by imposing a set of unbiasedness restrictions. In particular, we impose unbiasedness restrictions on nine observables closest to the economic interpretation of each of the factors (see shading areas in Table 1). ${ }^{12}$ This results in an exactly identified system (along the lines of Proposition 2 in Geweke \& Singleton (1981)). This exactly identified latent factor model is labelled as the "unrestricted model".

Second, (over-) identifying restrictions are imposed in the form of exclusion restrictions (see Table 1). Generally, the identification scheme is based on two strategies. First, exclusion restrictions are primarily imposed on slow-moving variables while fast-moving observables are left unrestricted (except for housing starts and stock market observations). ${ }^{13}$ This modeling choice is motivated by the idea that fast moving variables, containing a speculative component, can be considered as general and timely information variables for macroeconomic developments. Second, we differentiate between nominal, real, information, and policy factors. We define: one nominal factor (inflation factor); four real factors (unemployment, economic activity, consumption, and hours in production factors); three information factors (housing, commodity price, and stock market factors);

\footnotetext{
${ }^{12}$ The target observables of the factors are: the CPI-all items index (series 108) for the inflation factor $(\pi)$; the Unemployment Rate all workers (series 26) for the unemployment factor $\left(u_{n}\right)$; the Industrial Production-total index (series 16) for the economic activity factor (y); Personal Consumption Expenditure all items (series 49) for the consumption factor (c); Average weekly Hours of Production in manufacturing (series 47 ) for the hours in production factor (hrs); Housing Starts non-farm (series 54) for the housing factor (h); NAPM commodity price index (series 102) for the commodity price factor (pcom); The effective federal funds rate (series 77 ) by the monetary policy rate factor $(i)$; and finally the NYSE stock price index (series 66 ) for the stock market factor $(s)$. See appendix A for the definition and numbers assigned to each observable in the data panel.

${ }^{13}$ We use the definition of fast- and slow-moving variables of Bernanke et al. (2005) except housing starts and stock market returns, which we assume not to respond contemporaneously to some factors. This assumption helps empirically to distinguish a housing factor from a stock market factor.
} 
and one policy factor (monetary policy factor). In our identification strategy, nominal factors exclude all types of real observables as (contemporaneous) information variables. In the same way, real factors exclude nominal variables. Information factors exclude all slow-moving real and nominal observables. Finally, the policy factor loads freely on all observables. Details on the restrictions per variable are listed in Table 1 and described in more detail in Appendix B.

A final set of exclusion restrictions identifies the structural shocks through a standard Cholesky decomposition of the variance-covariance matrix of disturbances in the state equation. The ordering used in the analysis is as follows: $\pi, u_{n}, y, c$, $h r s$, pcom, $i, s$. This ordering is in line with the identification of monetary policy shocks in the literature (see for example Christiano et al. (1999)).

\subsection{Empirical Results}

\subsubsection{Identification restrictions and model performance}

Our identification scheme (see section 2) involves 482 over-identifying restrictions. In this section we provide a statistical test on these restrictions. In particular, we perform an $L R$-test of our restricted model against the unrestricted (exactly identified) model. We complement this test by a number of measures of fit including $R^{2}, A I C, B I C$, the log-likelihood value, and $I C_{p 2}^{*}$, a modified version of the Bai \& Ng (2002) $I C_{p 2}$ panel information criterion (see Doz et al. (2006)). Table 2 reports the results. As expected, the over-identifying restrictions are rejected at the usual significance level. Moreover, the values of the information criteria $\left(A I C, B I C\right.$ and $\left.I C_{p 2}^{*}\right)$ are higher for the restricted model. Interestingly, despite the statistical rejection of the model, we observe that the economic costs of the restrictions is relatively small. In particular, the cost of imposing 482 over-identifying restrictions is a decrease in overall (simple average) $R^{2}$ of approximately four percentage points, from $57.0 \%$ to $53.2 \%$. As a result, little is lost by imposing the over-identifying restrictions and we are willing to pay the price of a slight reduction in overall $R^{2}$ for economically interpretable factors. ${ }^{14}$

\footnotetext{
${ }^{14}$ Similar drops in R-square have been reported by Reis \& Watson (2008). In a related dynamic factor model they estimate a measure of pure inflation by imposing a unit loading on
} 
Insert Table 2

The general performance (explanatory power) of the restricted nine factor model is in line with the literature. Specifically, the average $R^{2}$ of $53.2 \%$ of our model is in line with the performance of large unrestricted DFMs for the US economy (e.g. Bai \& Ng (2007), Bork (2008) and Yu (2008)). Also, the value of average $R^{2}$ of our model corresponds to the value one would obtain from the Stock \& Watson (2002b) principal components approach with six factors. These findings suggest that the over-identifying restrictions and the implied economic interpretation of the factors can be obtained without major loss in fitting the dominant dimensions of variation in the panel.

\subsubsection{Implied factors}

Table 3 reports the estimates of free factor loadings as well as the total variance explained by the common factors $\left(R^{2}\right)$ for each of our observables. Figures 1 till 3 give a graphical representation of the estimated factor loadings for each of the nine retained factors. Overall, the statistics reported in Table 3 support the economic interpretation of the latent factors. In particular, the signs of estimated factor loadings are in line with theory. Also, the retrieved factors capture most of the variation in the key variables (with many $R^{2} s$ above $90 \%$ ). Figure 4 displays the factors as retrieved from the panel.

\section{Insert Figures 4 till 3 and Table 3}

Specifically, we find that the inflation factor $(\pi)$ closely tracks the CPI- $u$ all items inflation. Moreover, the R-squared is higher than the one based on the inflation factor identified by Bernanke et al. (2005) (96\% instead of 87\%). ${ }^{15}$ The estimated factor loadings on other CPI and PPI inflation series are significantly positive and the common component captures a substantial part of the variation

each of 187 US sectoral price indices. Using $t$-tests they reject the null hypothesis of unit loadings on their pure inflation factor. They report that imposing these restrictions only decreases the $R^{2}$ by less than $3 \%$ for eighty percent of the 187 observables.

${ }^{15}$ Bernanke et al. (2005) use an exactly-identified four-factor FAVAR model. 
in these series.

The unemployment factor $\left(u_{n}\right)$ captures approximately $73 \%$ of the variation in the target unemployment variable, i.e. Unemployment rate all workers. Other unemployment measures load significantly and positively on this factor. Note too that this factor also contributes significantly to the variation in the payroll variables and capacity utilization. As expected, loadings are typically negative for employment, payroll and capacity utilization variables.

The economic activity factor $(y)$ explains up to $97 \%$ of growth in industrial production (the target variable) and also fits reasonably well the different components of industrial production. Exceptions are non-durables, mining and utilities. Moreover, loadings for industrial production components are in general positive. The economic activity factor also contributes to the variation of payroll, income and employment variables. The consumption factor $(c)$ is restricted to load only on the five personal expenditure series in addition to the fast-moving variables. The one-to-one restrictions help to extract a consumption factor that explains 67 percent in the total personal expenditure series which is significantly higher than the $6-10 \%$ reported by Bernanke et al. (2005) and Bork (2008). Note too that estimated factor loadings suggest a close link between consumption of durables and the consumption factor. Other consumption components, i.e. non-durables and services, remain largely unrelated to the consumption factor as indicated by the low $R^{2}$. The hours in production factor ( $h r s$ ) explains average weekly overtime hours for production workers in manufacturing almost perfectly, $R^{2}=93 \%$. Furthermore, as suggested by the loadings, this factor significantly contributes to the dynamics of capacity utilization and help-wanted ads dynamics.

The housing factor $(h)$ explains $93 \%$ of total non-farm housing starts and authorizations while the commodity price factor (pcom) only captures $39 \%$ in monthly commodity price inflation as measured by movement in the NAPM commodity price index. The stock market factor $(s)$ explains more than $97 \%$ of variation in the NYSE index. This factor also explains well price movements for the S\&P500. Price earnings or dividend ratios do not load significantly on the stock market factor. The latter feature is probably explained by the fact that the stock market factor models stock returns, while levels of the price dividend and earnings 
ratios are included in the data set. Finally, the monetary policy factor tracks, by construction, perfectly the federal funds rate. In addition, the factor explains most of the variation in the remaining interest rate variables such as yields and spreads. Loadings for yields and spreads conform to the standard term structure literature.

\subsubsection{Measuring the impact of monetary policy}

We use our model to analyze the overall impact of monetary policy shocks on the US economy. To facilitate comparison with the literature we do not present the impulse response functions (IRFs) of the factors themselves. Instead, we focus on the IRFs of twenty key measures covering the US economy, as implied by the factor model (e.g. Bernanke et al. (2005)). More specifically, we analyze the federal funds rate, the yen per US dollar exchange rate, the level of industrial production, the consumer price level (CPI), monetary aggregates, the capacity utilization, the (un)employment level, the average hourly earnings, the level of consumption and consumer confidence expectations as key indicators for the macroeconomy. Additionally, we cover housing starts and two financial market indicators: the dividend yield on the $\mathrm{S} \& \mathrm{P}$ and the five year treasury yield.

\section{Insert Figure 5}

Figure 5 displays the IRFs of each of these variables to a 25 basis points monetary policy shock. The unit of the IRFs is the standard deviation of the respective series. Our IRFs depicted in Figure 5, are as expected and in line with the literature (see Christiano et al. (1999)). The empirical plausibility of the IRFs, therefore, suggests that the model is able to identify accurately the key macroeconomic transmission mechanisms and shocks.

Several observations can be made in this respect. First, unlike standard smallscale VAR models, we do no longer observe a price puzzle. Second, a contractionary monetary policy shock has a negative impact on output where the maximal effect is reached within one year. Third, long-run neutrality of monetary pol- 
icy cannot be rejected. In particular, monetary policy shocks only have a temporary effect on production, consumption, capacity utilization, and (un)employment levels. Fourth, the impact of temporary policy shocks is initially negative on the consumption expectations but then reverses before the impact becomes neutral in the long-run. Finally, the results show a significant impact of monetary policy shocks on financial markets. Monetary policy tightening increases the bond yields with the short-term yields responding more than the long-term yields, as illustrated by the IRF of the 3 month and 5 year yield. However, given the moderate persistence of the policy shocks (see the IRF of the federal funds rate), the impact on bond yields of monetary policy shocks remains relatively small and temporary. Real estate markets, as illustrated by the IRF of the housing starts, initially respond strongly to the monetary policy shock although there is no long-run effect. Following a monetary tightening, the dividend yield tends to adjust temporarily upwards while the yen tends to depreciate against the US dollar. These IRFs match both the responses reported in Banbura et al. (2008), using a BVAR and Bernanke et al. (2005) using a FAVAR.

\section{Insert Figure 6 and Table 4}

Table 4 and Figure 6 present the variance decomposition of the selected variables at alternative forecasting horizons. This tool allows us to assess the relative importance of monetary policy shocks in the overall variation of the series. Our results are broadly in line with those reported both in Banbura et al. (2008) and Bernanke et al. (2005). In line with these studies, we observe that monetary shocks do not have an important long-run (60 month) impact on the forecast error variance of a broad selection of key macroeconomic and financial variables. Specifically, we find that a monetary policy shock explains less than $12 \%$ of the variation in industrial production, consumer prices, commodity prices, (un)employment, new orders for any forecast horizon and virtually zero for consumption and money base. Unlike Bernanke et al. (2005), however, we do not find a large significant long-run effect of monetary policy shocks on the federal funds rate and the bond yields. The estimates reported in Table 4 indicate that monetary policy shocks are only mildly persistent and only account for approx- 
imately $3 \%$ to $7 \%$ of total long-run variation in the federal funds rate and the bond yields. Banbura et al. (2008), reporting similarly small numbers, argue that this may be explained by the size of the model. ${ }^{16}$

\section{Conclusion}

This paper has proposed a methodology to identify factors within the framework of dynamic factor models. We impose an economic interpretation on the static factors through a set of over-identifying restrictions on the factor loadings. We modify the standard estimation methodology to incorporate these over-identifying loading restrictions. In particular, following Shumway \& Stoffer (1982) and Wu et al. (1996), the appropriate parameter estimators and filters based on the EM algorithm are discussed.

In the empirical application the paper focuses on identifying a set of nine factors with economic interpretation. These factors represent key measures of the US economy such as inflation, unemployment, economic activity, consumption, state of the business cycle, residential investments, financial markets and monetary policy. The obtained factors are empirically plausible measures for each of the targeted key concepts, listed above. Subsequently, we use the model to assess the overall impact of monetary policy on the US economy. Our results are in line with those obtained using alternative methods on large panels, e.g. FAVARs or large BVARs.

\footnotetext{
${ }^{16}$ The larger the model, the more shocks can be identified and the smaller the likelihood of misspecification of the monetary policy shocks. In this model we identify nine structural shocks, which is significantly higher than the number of structural shocks identified by Bernanke et al. (2005).
} 


\section{References}

Alessi, L., Barigozzi, M. \& Capasso, M. (2007), 'Dynamic factor GARCH: Multivariate volatility forecast for a large number of series', Laboratory of Economics and Management (LEM), Sant'Anna School of Advanced Studies .

Altug, S. (1989), 'Time to build and aggregate fluctuations: some new evidence', International Economic Review 30(4), 889-920.

Bai, J. \& Ng, S. (2002), 'Determining the number of factors in approximate factor models', Econometrica 70(1), 191-221.

Bai, J. \& Ng, S. (2007), 'Determining the number of primitive shocks in factor models', Journal of Business \&6 Economic Statistics 25, 52-60.

Banbura, M., Giannone, D. \& Reichlin, L. (2008), 'Large bayesian VARs', Journal of Applied Econometrics (forthcoming).

Bernanke, B. S. \& Boivin, J. (2003), 'Monetary policy in a data-rich environment', Journal of Monetary Economics 50(3), 525-546.

Bernanke, B. S., Boivin, J. \& Eliasz, P. (2005), 'Measuring the effects of monetary policy: a factor-augmented vector autoregressive (FAVAR) approach', The Quarterly Journal of Economics pp. 387-422.

Bjørnland, H. \& Leitemo, K. (2009), 'Identifying the interdependence between US monetary policy and the stock market', Journal of Monetary Economics (forthcoming).

Blanchard, O. J. \& Quah, D. (1989), 'The dynamic effects of aggregate demand and supply disturbances', American Economic Review 79(4), 655-73.

Boivin, J. \& Giannoni, M. (2006), Dsge models in a data-rich environment, Working Paper 12772, National Bureau of Economic Research.

Boivin, J., Giannoni, M. P. \& Mihov, I. (2009), 'Sticky prices and monetary policy: Evidence from disaggregated us data', American Economic Review 99(1), 350-84. 
Bork, L. (2008), Estimating US monetary policy shocks using a factor-augmented vector autoregression: An EM algorithm approach. CREATES Research Paper 2009-11, University of Aarhus.

Campbell, J. Y., Lo, A. \& MacKinlay, C. (1997, ch. 2), The Econometrics of Financial Markets, Princeton University Press, Princeton.

Chamberlain, G. \& Rothschild, M. (1983), 'Arbitrage, factor structure, and meanvariance analysis on large asset markets', Econometrica 51(5), 1281-1304.

Christiano, L. J., Eichenbaum, M. \& Evans, C. L. (1999), Monetary policy shocks: What have we learned and to what end?, in J. B. Taylor \& M. Woodford, eds, 'Handbook of Macroeconomics', Vol. 1A, Elsevier Science, North Holland, New York, pp. 65-148.

de Jong, P. (1989), 'Smoothing and interpolation with the state-space model', Journal of the American Statistical Association 84, 1085-1088.

de Jong, P. \& Mackinnon, M. J. (1988), 'Covariances for smoothed estimates in state space models', Biometrika (75), 601-602.

Diebold, F. X., Li, C. \& Yue, V. Z. (2008), 'Global yield curve dynamics and interactions: A dynamic Nelson-Siegel approach', Journal of Econometrics 146(2), 351-363.

Doz, C., Giannone, D. \& Reichlin, L. (2006), A quasi maximum likelihood approach for large approximate dynamic factor models. European Central Bank Working Paper no. 674.

Doz, C., Giannone, D. \& Reichlin, L. (2007), A two-step estimator for large approximate dynamic factor models based on Kalman filtering, CEPR Discussion Paper 6043, Centre for Economic Policy Research.

Forni, M., Giannone, D., Lippi, M. \& Reichlin, L. (2008), 'Opening the black box: Structural factor models with large cross-sections', Econometric Theory, Vol. 25, No. 05, Pages 1319-1347.

Forni, M., Hallin, M., Lippi, M. \& Reichlin, L. (2000), 'The generalized dynamicfactor model: Identification and estimation', The Review of Economics and Statistics 82(4), 540-554. 
Forni, M., Hallin, M., Lippi, M. \& Reichlin, L. (2001), 'Coincident and leading indicators for the euro area', Economic Journal 111(471), 62-85.

Forni, M., Hallin, M., Lippi, M. \& Reichlin, L. (2005), 'The generalized dynamic factor model: one sided estimation and forecasting', Journal of the American Statistical Association 100(471), 830-840.

Forni, M. \& Lippi, M. (2001), 'The generalized dynamic factor model: Representation theory', Econometric Theory 17(06), 1113-1141.

Forni, M. \& Reichlin, L. (1998), 'Let's get real: A factor analytical approach to disaggregated business cycle dynamics', Review of Economic Studies 65(3), 453-73.

Forni, M. \& Reichlin, L. (2001), 'Federal policies and local economies: Europe and the us', European Economic Review 45(1), 109-134.

Geweke, J. F. \& Singleton, K. J. (1981), 'Maximum likelihood "confirmatory" factor analysis of economic time series', International Economic Review 22(1), 3754 .

Giannone, D., Reichlin, L. \& Sala, L. (2002), Tracking Greenspan: Systematic and unsystematic monetary policy revisited. CEPR Discussion Papers no. 3550.

Giannone, D., Reichlin, L. \& Sala, L. (2004), Monetary policy in real time, in M. Gertler \& K. Rogoff, eds, 'NBER Macroeconomic Annual 2004', Vol. 19, MIT Press.

Hallin, M. \& Liska, R. (2007), 'Determining the number of factors in the generalized factor model', Journal of the American Statistical Association 102, 603617.

Houssa, R. (2008a), 'Monetary union in west africa and asymmetric shocks: A dynamic structural factor model approach', Journal of Development Economics Vol. 85, 319-347.

Houssa, R. (2008b), Sources of Fluctuations: World, Regional, and National Factors, In Macroeconomic Fluctuations in Developing Countries, PhD thesis, KULeuven. 
Ingersoll, Jonathan E, J. (1984), 'Some results in the theory of arbitrage pricing', Journal of Finance 39(4), 1021-39.

Jungbacker, B. \& Koopman, S. J. (2008), Likelihood-based analysis for dynamic factor models, Tinbergen Institute Discussion Papers 08-007/4, Tinbergen Institute.

Kim, C.-J. \& Nelson, C. R. (1999), State-Space Models with Regime Switching, The MIT Press.

Kose, A. M., Otrok, C. \& Whiteman, C. (2003), 'International business cycles: World, region, and country-specific factors', American Economic Review 93(4), 1216-1239.

Lawley, D. N. \& Maxwell, A. E. (1971), Factor Analysis as a Statistical Method (Butterworths Mathematical Texts), 2nd. edn, Butterworths, London.

Leeper, E. M., Sims, C. A. \& Zha, T. (1996), 'What does monetary policy do?', Brookings Papers on Economic Activity 27(1996-2), 1-78.

Ludvigson, S. C. \& Ng, S. (2007), 'The empirical risk-return relation: A factor analysis approach', Journal of Financial Economics 83(1), 171-222.

Ludvigson, S. C. \& Ng, S. (2008), 'Macro factors in bond risk premia', The Review of Financial Studies (forthcoming).

Mönch, E. (2008), 'Forecasting the yield curve in a data-rich environment: A no-arbitrage factor-augmented VAR approach', Journal of Econometrics 146(1), 26-43.

Otrok, C. \& Whiteman, C. H. (1998), 'Bayesian leading indicators: Measuring and predicting economic conditions in Iowa', International Economic Review 39(4), 997-1014.

Reis, R. \& Watson, M. W. (2008), Relative goods' prices, pure inflation, and the Philips correlation. American Economic Journal Macroeconomics (forthcoming).

Sargent, T. J. (1989), 'Two models of measurements and the investment accelerator', Journal of Political Economy 97(2), 251-287. 
Shumway, R. H. \& Stoffer, D. S. (1982), 'An approach to time series smoothing and forecasting using the EM algorithm', Journal of Time Series Analysis 3, 253-226.

Sims, C. (1980), 'Macroeconomics and reality', Econometrica 48, 1-48.

Stock, J. H. \& Watson, M. W. (2002a), 'Forecasting using principal components from a large number of predictors', Journal of the American Statistical Association 97, 1167-1179.

Stock, J. H. \& Watson, M. W. (2002b), 'Macroeconomic forecasting using diffusion indexes', Journal of Business Economics and Statistics XX:II, 147-162.

Stock, J. H. \& Watson, M. W. (2005), Implications of dynamic factor models for VAR analysis, Working Paper 11467, National Bureau of Economic Research.

Uhlig, H. (2005), 'What are the effects of monetary policy on output? Results from an agnostic identification procedure', Journal of Monetary Economics 52(2), 381-419.

Wu, L. S.-Y., Pai, J. S. \& Hosking, J. (1996), 'An algorithm for estimating parameters of state-space models', Statistics and Probability Letters 28, 99106.

Yu, W.-C. (2008), 'Macroeconomic and financial market volatilities: an empirical evidence of factor model', Economics Bulletin 3(33), 1-18. 


\section{A Data description}

Data are from Bernanke et al. (2005).

First column: A superscript indicates that an exactly identifying restriction has been imposed on this variable, i.e. $108^{[1]}$ indicates that an identifying restriction has been imposed on this variable for the first factor. The second column is a mnemonic and a * indicates a "slow-moving" variable. Fourth column contains transformation codes. "level" indicates an un-transformed variable, say $x_{t}$. "ln" means $\ln x_{t}$ and " $\Delta \ln$ " means $\ln x_{t}-\ln x_{t-1}$.

Real output and income

\begin{tabular}{|c|c|c|}
\hline 1 & $\mathrm{IPP}^{*}$ & 1959:01-2001:08 \\
\hline 2 & $\mathrm{IPF}^{*}$ & 1959:01-2001:08 \\
\hline 3 & IPC* & 1959:01-2001:08 \\
\hline 4 & IPCD* & 1959:01-2001:08 \\
\hline 5 & IPCN* & 1959:01-2001:08 \\
\hline 6 & IPE* & 1959:01-2001:08 \\
\hline 7 & IPI* & 1959:01-2001:08 \\
\hline 8 & IPM* & 1959:01-2001:08 \\
\hline 9 & IPMD* & 1959:01-2001:08 \\
\hline 10 & IPMND* & 1959:01-2001:08 \\
\hline 11 & IPMFG* & 1959:01-2001:08 \\
\hline 12 & $\mathrm{IPD}^{*}$ & 1959:01-2001:08 \\
\hline 13 & IPN* & 1959:01-2001:08 \\
\hline 14 & IPMIN* & 1959:01-2001:08 \\
\hline 15 & IPUT* & 1959:01-2001:08 \\
\hline $16^{[3]}$ & $\mathrm{IP}^{*}$ & 1959:01-2001:08 \\
\hline 17 & IPXMCA* & 1959:01-2001:08 \\
\hline 18 & PMI* & 1959:01-2001:08 \\
\hline 19 & $\mathrm{PMP}^{*}$ & 1959:01-2001:08 \\
\hline 20 & GMPYQ* & 1959:01-2001:08 \\
\hline 21 & GMYXPQ* & 1959:01-2001:08 \\
\hline
\end{tabular}

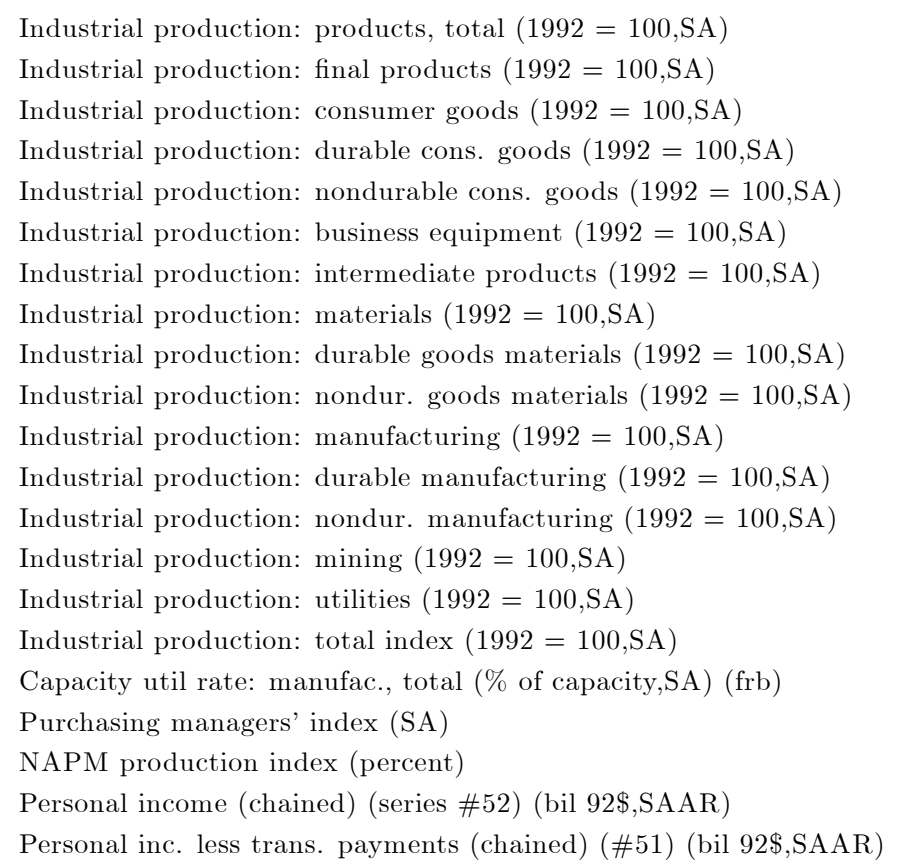


(Un)employment and hours

\begin{tabular}{|c|c|c|}
\hline 22 & LHEL* & 1959:01-2001:08 \\
\hline 23 & LHELX* & 1959:01-2001:08 \\
\hline 24 & LHEM* & 1959:01-2001:08 \\
\hline 25 & LHNAG* & 1959:01-2001:08 \\
\hline $26^{[2]}$ & LHUR* & 1959:01-2001:08 \\
\hline 27 & LHU680* & 1959:01-2001:08 \\
\hline 28 & LHU5* & 1959:01-2001:08 \\
\hline 29 & LHU14* & 1959:01-2001:08 \\
\hline 30 & LHU15* & 1959:01-2001:08 \\
\hline 31 & LHU $26^{*}$ & 1959:01-2001:08 \\
\hline 32 & LPNAG* & 1959:01-2001:08 \\
\hline 33 & $\mathrm{LP}^{*}$ & 1959:01-2001:08 \\
\hline 34 & LPGD* & 1959:01-2001:08 \\
\hline 35 & LPMI* & 1959:01-2001:08 \\
\hline 36 & LPCC* & 1959:01-2001:08 \\
\hline 37 & LPEM* & 1959:01-2001:08 \\
\hline 38 & LPED* & 1959:01-2001:08 \\
\hline 39 & LPEN* & 1959:01-2001:08 \\
\hline 40 & LPSP* & 1959:01-2001:08 \\
\hline 41 & LPTU* & 1959:01-2001:08 \\
\hline 42 & $\mathrm{LPT}^{*}$ & 1959:01-2001:08 \\
\hline 43 & LPFR* & 1959:01-2001:08 \\
\hline 44 & LPS* & 1959:01-2001:08 \\
\hline 45 & $\mathrm{LPGOV}^{*}$ & 1959:01-2001:08 \\
\hline 46 & LPHRM* & 1959:01-2001:08 \\
\hline $47^{[5]}$ & LPMOSA* & 1959:01-2001:08 \\
\hline 48 & PMEMP* & 1959:01-2001:08 \\
\hline
\end{tabular}

Index of help-wanted advertising in newspapers $(1967=100 ; \mathrm{SA})$

Employment: ratio; help-wanted ads: no. unemployed clf

Civilian labor force: employed, total (thous.,SA)

Civilian labor force: employed, nonag. industries (thous.,SA)

Unemployment rate: all workers, 16 years and over $(\%, \mathrm{SA})$

Unemploy. by duration: average (mean) duration in weeks (SA)

Unemploy. by duration: pers unempl. less than 5 wks (thous.,SA)

Unemploy. by duration: pers unempl. 5 to 14 wks (thous.,SA)

Unemploy. by duration: pers unempl. $15 \mathrm{wks}=$ (thous.,SA)

Unemploy. by duration: pers unempl. 15 to 26 wks (thous.,SA)

Employees on nonag. payrolls: total (thous.,SA)

Employees on nonag. payrolls: total, private (thous.,SA)

Employees on nonag. payrolls: goods-producing (thous.,SA)

Employees on nonag. payrolls: mining (thous.,SA)

Employees on nonag. payrolls: contract construc. (thous.,SA)

Employees on nonag. payrolls: manufacturing (thous.,SA)

Employees on nonag. payrolls: durable goods (thous.,SA)

Employees on nonag. payrolls: nondurable goods (thous.,SA)

Employees on nonag. payrolls: service-producing (thous.,SA)

Employees on nonag. payrolls: trans. and public util. (thous.,SA)

Employees on nonag. payrolls: wholesale and retail (thous.,SA)

Employees on nonag. payrolls: finance, ins. and real est (thous.,SA)

Employees on nonag. payrolls: services (thous.,SA)

Employees on nonag. payrolls: government (thous.,SA)

Avg. weekly hrs. of production wkrs.: manufacturing (sa)

Avg. weekly hrs. of prod. wkrs.: mfg., overtime hrs. (sa)

NAPM employment index (percent)

\section{Consumption}

$\begin{array}{llll}49^{[4]} & \text { GMCQ }^{*} & 1959: 01-2001: 08 & \Delta \ln \\ 50 & \text { GMCDQ }^{*} & 1959: 01-2001: 08 & \Delta \ln \\ 51 & \text { GMCNQ }^{*} & 1959: 01-2001: 08 & \Delta \ln \\ 52 & \text { GMCSQ }^{*} & 1959: 01-2001: 08 & \Delta \ln \\ 53 & \text { GMCANQ }^{*} & 1959: 01-2001: 08 & \Delta \ln \end{array}$

Housing starts and sales

$\begin{array}{llll}54^{[6]} & \text { HSFR } & 1959: 01-2001: 08 & \text { ln } \\ 55 & \text { HSNE } & 1959: 01-2001: 08 & \text { ln } \\ 56 & \text { HSMW } & 1959: 01-2001: 08 & \text { ln } \\ 57 & \text { HSSOU } & 1959: 01-2001: 08 & \text { ln } \\ 58 & \text { HSWST } & 1959: 01-2001: 08 & \text { ln } \\ 59 & \text { HSBR } & 1959: 01-2001: 08 & \text { ln } \\ 60 & \text { HMOB } & 1959: 01-2001: 08 & \text { ln }\end{array}$

Pers cons exp (chained) - total (bil 92\$,SAAR)

Pers cons exp (chained) - tot. dur. (bil 96\$,SAAR)

Pers cons exp (chained) - nondur. (bil 92\$,SAAR)

Pers cons exp (chained) - services (bil 92\$,SAAR)

Personal cons expend (chained) — new cars (bil 96\$,SAAR)
Housing starts: nonfarm (1947-1958); tot. (

Housing starts: northeast (thous.u.)s.a.

Housing starts: midwest (thous.u.)s.a.

Housing starts: south (thous.u.)s.a.

Housing starts: west (thous.u.)s.a.

Housing authorized: total new priv housing (thous.,SAAR)

Mobile homes: manufacturers' shipments (thous. of units,SAAR) 
Real inventories, ordes and unfilled orders

$\begin{array}{llll}61 & \text { MNV } & \text { 1959:01-2001:08 } & \text { level } \\ 62 & \text { PMNO } & \text { 1959:01-2001:08 } & \text { level } \\ 63 & \text { PMDEL } & \text { 1959:01-2001:08 } & \text { level } \\ 64 & \text { MOCMQ } & \text { 1959:01-2001:08 } & \Delta \text { ln } \\ 65 & \text { MSONDQ } & 1959: 01-2001: 08 & \Delta \text { ln }\end{array}$

NAPM inventories index (percent)

NAPM new orders index (percent)

NAPM vendor deliveries index (percent)

New orders (net) - consumer goods and materials, $1992 \$$ (bci)

New orders, nondefense capital goods, in 1992 \$s (bci)

\section{Stock prices}

$\begin{array}{llll}6^{[9]} & \text { FSNCOM } & \text { 1959:01-2001:08 } & \Delta \text { ln } \\ 67 & \text { FSPCOM } & 1959: 01-2001: 08 & \Delta \text { ln } \\ 68 & \text { FSPIN } & 1959: 01-2001: 08 & \Delta \text { ln } \\ 69 & \text { FSPCAP } & 1959: 01-2001: 08 & \Delta \text { ln } \\ 70 & \text { FSPUT } & 1959: 01-2001: 08 & \Delta \text { ln } \\ 71 & \text { FSDXP } & 1959: 01-2001: 08 & \text { level } \\ 72 & \text { FSPXE } & 1959: 01-2001: 08 & \text { level }\end{array}$

NYSE composite $(12 / 31 / 65=50)$

S\&P's composite $(1941-1943=10)$

S\&P's industrials $(1941-1943=10)$

S\&P's capital goods $(1941-1943=10)$

S\&P's utilities $(1941-1943=10)$

S\&P's composite common stock: dividend yield (\% per annum)

$\mathrm{S} \& \mathrm{P}$ 's composite common stock: price-earnings ratio $(\%, \mathrm{NSA})$

Foreign exchange rates

$\begin{array}{llll}73 & \text { EXRSW } & 1959: 01-2001: 08 & \Delta \ln \\ 74 & \text { EXRJAN } & 1959: 01-2001: 08 & \Delta \ln \\ 75 & \text { EXRUK } & 1959: 01-2001: 08 & \Delta \ln \\ 76 & \text { EXRCAN } & 1959: 01-2001: 08 & \Delta \ln \end{array}$

Foreign exchange rate: Switzerland (swiss franc per US\$)

Foreign exchange rate: Japan (yen per US\$)

Foreign exchange rate: United Kingdom (cents per pound)

Foreign exchange rate: Canada (canadian $\$$ per US\$)

Interest rates and spreads

$\begin{array}{llll}77^{[8]} & \text { FYFF } & \text { 1959:01-2001:08 } & \text { level } \\ 78 & \text { FYGM3 } & \text { 1959:01-2001:08 } & \text { level } \\ 79 & \text { FYGM6 } & \text { 1959:01-2001:08 } & \text { level } \\ 80 & \text { FYGT1 } & \text { 1959:01-2001:08 } & \text { level } \\ 81 & \text { FYGT5 } & \text { 1959:01-2001:08 } & \text { level } \\ 82 & \text { FYGT10 } & \text { 1959:01-2001:08 } & \text { level } \\ 83 & \text { FYAAAC } & \text { 1959:01-2001:08 } & \text { level } \\ 84 & \text { FYBAAC } & 1959: 01-2001: 08 & \text { level } \\ 85 & \text { SFYGM3 } & \text { 1959:01-2001:08 } & \text { level } \\ 86 & \text { SFYGM6 } & 1959: 01-2001: 08 & \text { level } \\ 87 & \text { SFYGT1 } & 1959: 01-2001: 08 & \text { level } \\ 88 & \text { SFYGT5 } & 1959: 01-2001: 08 & \text { level } \\ 89 & \text { SFYGT10 } & 1959: 01-2001: 08 & \text { level } \\ 90 & \text { SFYAAAC } & 1959: 01-2001: 08 & \text { level } \\ 91 & \text { SFYBAAC } & 1959: 01-2001: 08 & \text { level }\end{array}$

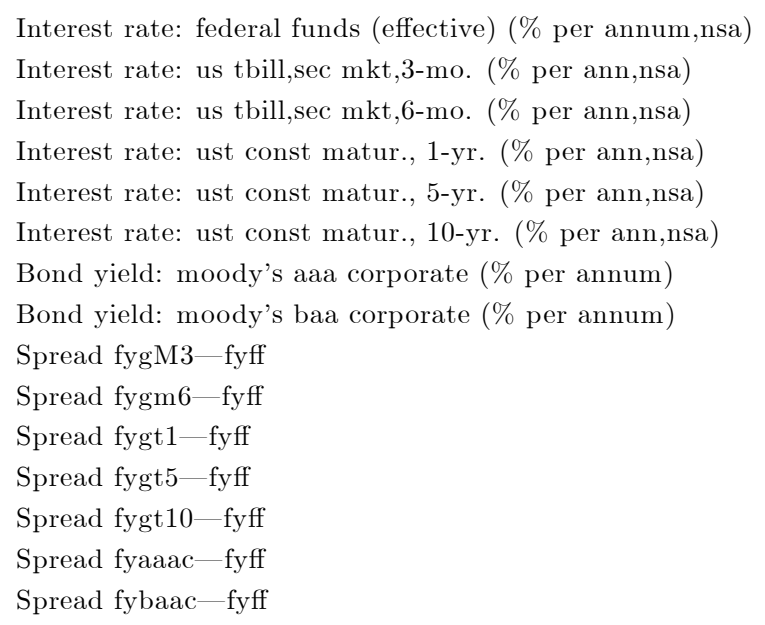


Money and credit quantity aggregates

$\begin{array}{llll}92 & \text { FM1 } & \text { 1959:01-2001:08 } & \Delta \ln \\ 93 & \text { FM2 } & 1959: 01-2001: 08 & \Delta \ln \\ 94 & \text { FM3 } & 1959: 01-2001: 08 & \Delta \ln \\ 95 & \text { FM2DQ } & 1959: 01-2001: 08 & \Delta \ln \\ 96 & \text { FMFBA } & 1959: 01-2001: 08 & \Delta \ln \\ 97 & \text { FMRRA } & 1959: 01-2001: 08 & \Delta \ln \\ 98 & \text { FMRNBA } & 1959: 01-2001: 08 & \Delta \ln \\ 99 & \text { FCLNQ } & 1959: 01-2001: 08 & \Delta \ln \\ 100 & \text { FCLBMC } & 1959: 01-2001: 08 & \text { level } \\ 101 & \text { CCINRV } & 1959: 01-2001: 08 & \Delta \ln \end{array}$

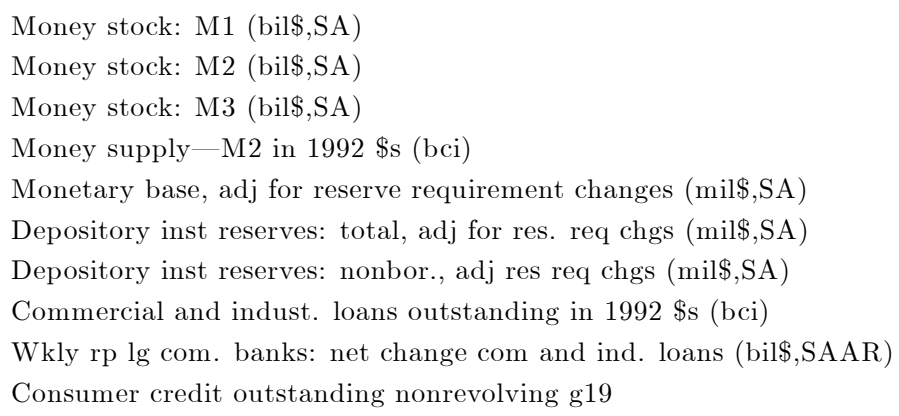

Price indexes

\begin{tabular}{|c|c|c|c|}
\hline $102^{[7]}$ & $\mathrm{PMCP}$ & 1959:01-2001:08 & leve \\
\hline 103 & PWFSA* & 1959:01-2001:08 & $\Delta \operatorname{lr}$ \\
\hline 104 & PWFCSA* & 1959:01-2001:08 & $\Delta \operatorname{lr}$ \\
\hline 105 & PWIMSA* & 1959:01-2001:08 & $\Delta \operatorname{lr}$ \\
\hline 106 & PWCMSA* & 1959:01-2001:08 & $\Delta \operatorname{lr}$ \\
\hline 107 & PSM99Q* & 1959:01-2001:08 & $\Delta \operatorname{lr}$ \\
\hline $108^{[1]}$ & PUNEW* & 1959:01-2001:08 & $\Delta \operatorname{lr}$ \\
\hline 109 & PU83* & 1959:01-2001:08 & $\Delta \operatorname{lr}$ \\
\hline 110 & PU84* & 1959:01-2001:08 & $\Delta \operatorname{lr}$ \\
\hline 111 & PU85* & 1959:01-2001:08 & $\Delta \operatorname{lr}$ \\
\hline 112 & PUC* & 1959:01-2001:08 & $\Delta \operatorname{lr}$ \\
\hline 113 & PUCD* & 1959:01-2001:08 & $\Delta \operatorname{lr}$ \\
\hline 114 & PUS* & 1959:01-2001:08 & $\Delta \operatorname{lr}$ \\
\hline 115 & PUXF* & 1959:01-2001:08 & $\Delta \operatorname{lr}$ \\
\hline 116 & PUXHS* & 1959:01-2001:08 & $\Delta \operatorname{lr}$ \\
\hline 117 & PUXM* & 1959:01-2001:08 & $\Delta \ln$ \\
\hline
\end{tabular}

NAPM commodity prices index (\%)

PPI: finished goods $(82=100, \mathrm{SA})$

PPI: finished consumer goods $(82=100, \mathrm{SA})$

PPI: intermed mat. sup and components $(82=100, \mathrm{SA})$

PPI: crude materials $(82=100, \mathrm{SA})$

Index of sensitive materials prices $(1990=100)(\mathrm{bci}-99 \mathrm{a})$

CPI-u: all items $(82-84=100, \mathrm{SA})$

CPI-u: apparel and upkeep $(82-84=100$, SA $)$

CPI-u: transportation $(82-84=100, \mathrm{SA})$

CPI-u: medical care $(82-84=100, \mathrm{SA})$

CPI-u: commodities $(82-84=100, \mathrm{SA})$

CPI-u: durables $(82-84=100, \mathrm{SA})$

CPI-u: services $(82-84=100, \mathrm{SA})$

CPI-u: all items less food $(82-84=100$, SA $)$

CPI-u: all items less shelter $(82-84=100, \mathrm{SA})$

CPI-u: all items less medical care $(82-84=100, \mathrm{SA})$

Average hourly earnings

$\begin{array}{llll}118 & \text { LEHCC* } & 1959: 01-2001: 08 & \Delta \ln \\ 119 & \text { LEHM }^{*} & 1959: 01-2001: 08 & \Delta \ln \end{array}$

Avg hr earnings of constr wkrs: construction $(\$, S A)$

Avg hr earnings of prod wkrs: manufacturing $(\$, S A)$

\section{Miscellaneous}

120 HHSNTN 1959:01-2001:08 level U. of mich. index of consumer




\section{B Over-identifying loading restrictions}

The specific set of (over-) identifying restrictions can be summarized as follows; the inflation factor $(\pi)$ is identified by the unbiasedness restriction on CPI-u all items. Additionally, we allow other inflation measures to load on the inflation factor. With the inflation factor being a nominal factor, we exclude from the information set all real variables, e.g. industrial production.

For the four real factors we impose exclusion restrictions on nominal variables (e.g. CPI inflation). Additional exclusion restrictions limit the type of real variables acting as information variables for each of the factors. In particular, the unemployment factor $\left(u_{n}\right)$ is identified by the unbiasedness restriction on 'Unemployment all workers'. Other (un)employment variables and measures of payroll statistics and capacity utilization are included as additional information variables. All other slow-moving variables are excluded from the information set. The economic activity factor $(y)$, identified by the unbiasedness restriction on the Industrial Production (IP) total index series, uses IP variables next to employment and payroll series as additional state variables. The hours in production factor (hrs) measures the current over (under) production and is identified (by means of an unbiasedness restriction) through the overtime hours in production and manufacturing. As additional information variables we include variables such as capacity utilization rate, survey-based production indices (PMI, PMP) and help-wanted advertising to enter freely. We exclude (un)employment and IP growth as we consider them less informative with respect to the level of over and underproduction. The last real factor, i.e. the consumption factor $(c)$, is filtered from the observed consumption series in the panel with an unbiasedness restriction on 'Personal Consumption Expenditure' series and one-to-one restrictions on two consumption observables. Moreover, due to consumption smoothing, we do not expect strong contemporaneous correlations between production employment based statistics and consumption (growth). Therefore, we impose exclusion restrictions on production related variables.

The information and the policy factors measure particular features in the economy. More precisely, the housing factor $(h)$ is included as a residential investment 
factor. This factor is identified through an unbiasedness restriction on the total number of housing starts and uses as additional information variables other housing starts or authorization variables. We consider the housing factor to be mainly a forward-looking variable containing all relevant information. As such, exclusion restrictions are imposed on all slow-moving variables. The commodity price factor (pcom) aims at measuring cost-push factors due to price increases of raw materials or intermediate products. It is identified by means of the NAPM commodity price index. Moreover, the commodity price factor retrieves additional information from PPI data for crude and intermediate materials and from the index of sensitive materials. The monetary policy factor $(i)$ is directly measured by the effective federal funds rate. Finally, the stock market factor $(s)$ is related to returns on the NYSE index and uses S\&P500 stock market component indices as additional state variables. We allow all other fast-moving variables to load freely on the stock market factor allowing for direct interactions across financial markets. 
Table 1: Loading restrictions.

\begin{tabular}{|c|c|c|c|c|c|c|c|c|c|}
\hline Variable Names & $\pi$ & $u_{n}$ & $y$ & $c$ & hrs & $h$ & pcom & $i$ & $s$ \\
\hline 1) IP: products, total & 0 & 0 & $\mathrm{x}$ & 0 & 0 & 0 & 0 & $\mathrm{x}$ & 0 \\
\hline 2) İP: final products & 0 & 0 & $\mathrm{x}$ & 0 & 0 & 0 & 0 & $\mathrm{x}$ & 0 \\
\hline 3) IP: consumer & 0 & 0 & $\mathrm{x}$ & 0 & 0 & 0 & 0 & $\mathrm{x}$ & 0 \\
\hline 4) IP: durable cons. & 0 & 0 & $\mathrm{x}$ & 0 & 0 & 0 & 0 & $\mathrm{x}$ & 0 \\
\hline 5) IP: nondur. cons. & 0 & 0 & $\mathrm{x}$ & 0 & 0 & 0 & 0 & $\mathrm{x}$ & 0 \\
\hline 6) IP: bus. Equip & 0 & 0 & $\mathrm{x}$ & 0 & 0 & 0 & 0 & $\mathrm{x}$ & 0 \\
\hline 7) IP: intermediate & 0 & 0 & $\mathrm{x}$ & 0 & 0 & 0 & 0 & $\mathrm{x}$ & 0 \\
\hline 8) IP: materials & 0 & 0 & $\mathrm{x}$ & 0 & 0 & 0 & 0 & $\mathrm{x}$ & 0 \\
\hline 9) IP: durable goods & 0 & 0 & $\mathrm{x}$ & 0 & 0 & 0 & 0 & $\mathrm{x}$ & 0 \\
\hline 10) IP: nondur. goods & 0 & 0 & $\mathrm{x}$ & 0 & 0 & 0 & 0 & $\mathrm{x}$ & 0 \\
\hline 11) IP: manufacturing & 0 & 0 & $\mathrm{x}$ & 0 & 0 & 0 & 0 & $x$ & 0 \\
\hline 12 ) IP: dur. manuf & 0 & 0 & $\mathrm{x}$ & 0 & 0 & 0 & 0 & $\mathrm{x}$ & 0 \\
\hline 13 ) İP: nondur. manuf. & 0 & 0 & $\mathrm{x}$ & 0 & 0 & 0 & 0 & $\mathrm{x}$ & 0 \\
\hline 14) IP: mining & 0 & 0 & $\mathrm{x}$ & 0 & 0 & 0 & 0 & $\mathrm{x}$ & 0 \\
\hline 15) IP: utilities & 0 & 0 & $x$ & 0 & 0 & 0 & 0 & $\mathrm{x}$ & 0 \\
\hline 16) IP: total index & 0 & 0 & 1 & 0 & 0 & 0 & 0 & 0 & 0 \\
\hline 17) Capacity util rate & 0 & $\mathrm{x}$ & $\mathrm{x}$ & 0 & $\mathrm{x}$ & 0 & 0 & $\mathrm{x}$ & 0 \\
\hline 18) Pmi & 0 & 0 & $\mathrm{x}$ & 0 & $\mathrm{x}$ & 0 & 0 & $\mathrm{x}$ & 0 \\
\hline 19) NAPM prod. & 0 & 0 & $\mathrm{x}$ & 0 & $\mathrm{x}$ & 0 & 0 & $\mathrm{x}$ & 0 \\
\hline 20) Pers. Income & 0 & 0 & $x$ & 0 & \%” & $0 *$ & 0 & $\mathrm{x}$ & 0 \\
\hline 21$)$ Pers. Inc. - trans. & 0 & 0 & $x$ & 0 & 0 & 0 & 0 & $\mathrm{x}$ & 0 \\
\hline 22$)$ Help-wated & 0 & $x$ & $x$ & 0 & x & 0 & 0 & $\mathrm{x}$ & 0 \\
\hline 23) Empl. Help-wanted & 0 & $\mathrm{x}$ & $\mathrm{x}$ & 0 & x & 0 & $\dddot{0}$ & $\mathrm{x}$ & 0 \\
\hline 24$)$ Civ. Labor: empl., & 0 & $x$ & $x$ & 0 & 0 & 0 & 0 & $x$ & 0 \\
\hline 25$)$ Civilian labor: empl., & 0 & $x$ & $x$ & 0 & ר" & 0 & 0 & $\mathrm{x}$ & 0 \\
\hline 26$)$ UUnempl. Rate: ali wrks & 0 & 1 & 0 & 0 & 0 & 0 & 0 & 0 & 0 \\
\hline 27) UUnemp dur: mean & 0 & $\mathrm{x}$ & $\mathrm{x}$ & 0 & 0 & 0 & 0 & $\mathrm{x}$ & 0 \\
\hline 28$)$ Unemp dur. $<5$ w. & 0 & $x$ & $x$ & 0 & ö & 0 & ơ. & $\mathrm{x}$ & 0 \\
\hline 29$)$ Unemp dur. $5-14$ w & 0 & x & $x$ & 0 & 0 & $0 \%$ & $\dddot{0}$ & $\mathrm{x}$ & 0 \\
\hline 30) UUnemp dur. $15+$ w & 0 & x & $x$ & 0 & ő" & 0 & $\dddot{0}$ & $\mathrm{x}$ & 0 \\
\hline 31$)$ UUnemp dur. $15-26 \mathrm{w}$ & 0 & x & 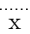 & 0 & ?̋" & $0 \%$ & \%̋ & $\mathrm{x}$ & 0 \\
\hline 32 ) Nonag payril:: total & 0 & 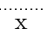 & $x$ & 0. & о̋ & 0 & ?̋. & $\mathrm{x}$ & 0 \\
\hline 33) Nonag payri:: total, & 0 & x & $x$ & 0 & ő" & 0 & "̋." & $\mathrm{x}$ & $\because \%$ \\
\hline 34$)$ Nonag payrl.: goods & 0 & $\mathrm{x}$ & $\mathrm{x}$ & 0 & 0 & 0 & 0 & $\mathrm{x}$ & 0 \\
\hline 35) Nonag payri.: mining & 0 & $\mathrm{x}$ & $\mathrm{x}$ & 0 & 0 & 0 & 0 & $\mathrm{x}$ & 0 \\
\hline 36$)$ Nonag payri.: contract & 0 & $\mathrm{x}$ & $\mathrm{x}$ & 0 & 0 & 0 & 0 & $\mathrm{x}$ & 0 \\
\hline 37$)$ Nonag payri.: manuf & 0 & $\mathrm{x}$ & $\mathrm{x}$ & 0 & 0 & 0 & 0 & $\mathrm{x}$ & 0 \\
\hline 38 ) Nonag payri.: durable & 0 & $\mathrm{x}$ & $\mathrm{x}$ & 0 & 0 & 0 & 0 & $\mathrm{x}$ & 0 \\
\hline 39 ) Nonag payril: nondur & 0 & $\mathrm{x}$ & $\mathrm{x}$ & 0 & 0 & 0 & 0 & $\mathrm{x}$ & 0 \\
\hline 40) Nonag payrl.: service & 0 & $\mathrm{x}$ & $\mathrm{x}$ & 0 & 0 & 0 & 0 & $\mathrm{x}$ & 0 \\
\hline 41) Nonag payri.: trans. & 0 & $\mathrm{x}$ & $\mathrm{x}$ & 0 & 0 & 0 & 0 & $\mathrm{x}$ & 0 \\
\hline 42$)$ Nonag payri.: sale & 0 & $\mathrm{x}$ & $\mathrm{x}$ & 0 & 0 & 0 & 0 & $\mathrm{x}$ & 0 \\
\hline 43 ) Nonag payril.: finance & 0 & $\mathrm{x}$ & $\mathrm{x}$ & 0 & 0 & 0 & 0 & $\mathrm{x}$ & 0 \\
\hline 44) Nonag payril.: services & 0 & $\mathrm{x}$ & $\mathrm{x}$ & 0 & 0 & 0 & 0 & $\mathrm{x}$ & 0 \\
\hline 45) Nonag payri.: gov. & 0 & $\mathrm{x}$ & $\mathrm{x}$ & 0 & 0 & 0 & 0 & $\mathrm{x}$ & 0 \\
\hline 46) Avg. W Wly hrs. prod & 0 & 0 & 0 & 0 & $\mathrm{u}$ & 0 & 0 & $\mathrm{x}$ & 0 \\
\hline 47) Avg. W kly overtime prod & 0 & 0 & 0 & 0 & 1 & 0 & 0 & 0 & 0 \\
\hline 48) NAPM Empl. Index & 0 & $\mathrm{x}$ & $\mathrm{x}$ & 0 & 0 & 0 & 0 & $\mathrm{x}$ & 0 \\
\hline 49) Pers cons exp: total & 0 & 0 & 0 & 1 & 0 & 0 & 0 & 0 & 0 \\
\hline 50) Pers cons exp: tot. & 0 & 0 & 0 & 1 & 0 & 0 & 0 & $\mathrm{x}$ & 0 \\
\hline 51) Pers cons exp: nondur. & 0 & 0 & 0 & 1 & 0 & 0 & 0 & $\mathrm{x}$ & 0 \\
\hline 52) Pers cons exp: services & 0 & 0 & 0 & $\mathrm{x}$ & 0 & 0 & $\dddot{0}$ & $\mathrm{x}$ & 0 \\
\hline 53) Pers cons exp: new cars & 0 & 0 & 0 & $\mathrm{x}$ & 0 & 0 & 0 & $\mathrm{x}$ & 0 \\
\hline 54) Housing starts: nonfarm & 0 & 0 & 0 & 0 & 0 & 1 & 0 & 0 & 0 \\
\hline 55$)$ Housing starts: N.E & 0 & x & $\mathrm{x}$ & 0 & 0 & $\mathrm{x}$ & 0 & $\mathrm{x}$ & 0 \\
\hline 56$)$ Housing starts: M.W & 0 & $x$ & $x$ & 0 & 0 & $\mathrm{x}$ & 0.. & $\mathrm{x}$ & 0 \\
\hline 57) Housing starts: S & 0 & $\mathrm{x}$ & $x$ & 0 & 0 & $\mathrm{x}$ & 0 & $\mathrm{x}$ & 0 \\
\hline 58 ) Housing starts: $\mathrm{S}$ & 0 & $\mathrm{x}$ & $\mathrm{x}$ & 0. & 0 & $\mathrm{x}$ & 0 & $\mathrm{x}$ & 0 \\
\hline 59 ) Housing auth. Tot new & 0 & $x$ & $x$ & 0 & 0 & $x$ & 0 & $x$ & 0 \\
\hline 60) Mobile homes & 0 & $x$ & $x$ & 0 & 0 & $\mathrm{x}$ & 0 & $x$ & 0 \\
\hline
\end{tabular}

The factors are denoted by the symbols $\left\{\pi, u_{n}, y, c, h r s, h, p c o m, i, s\right\}$ and describe general inflation, unemployment, economic activity (growth), consumption growth, hours in production, residential investments, commodity price inflation, federal funds rate and stock markets returns respectively. x denotes a free factor loading that is estimated. Shading areas cover loadings that are fixed with unbiasedness restrictions. 
Table 1 continued

\begin{tabular}{|c|c|c|c|c|c|c|c|c|c|}
\hline Variable Names & $\pi$ & $u_{n}$ & $y$ & $c$ & hrs & $h$ & pcom & $i$ & $s$ \\
\hline 61) NAPM inventories & $\mathrm{x}$ & $\mathrm{x}$ & $\mathrm{x}$ & $\mathrm{x}$ & $\mathrm{x}$ & $\mathrm{x}$ & $\mathrm{x}$ & $\mathrm{x}$ & $\mathrm{x}$ \\
\hline 62$)$ NAPM new orders & $\mathrm{x}$ & $\mathrm{x}$ & $\mathrm{x}$ & $\mathrm{x}$ & $\mathrm{x}$ & $\mathrm{x}$ & $\mathrm{x}$ & $\mathrm{x}$ & $\mathrm{x}$ \\
\hline 63) NAPM vendor deliv. & $\mathrm{x}$ & $\mathrm{x}$ & $\mathrm{x}$ & $\mathrm{x}$ & $\mathrm{x}$ & $\mathrm{x}$ & $\mathrm{x}$ & $\mathrm{x}$ & $\mathrm{x}$ \\
\hline 64$)$ New orders: cons goods & $\mathrm{x}$ & $\mathrm{x}$ & $\mathrm{x}$ & $\mathrm{x}$ & $\mathrm{x}$ & $\mathrm{x}$ & $\mathrm{x}$ & $\mathrm{x}$ & $\mathrm{x}$ \\
\hline 65$)$ New orders: nondefense & $\mathrm{x}$ & $\mathrm{x}$ & $\mathrm{x}$ & $\mathrm{x}$ & $\mathrm{x}$ & $\mathrm{x}$ & $\mathrm{x}$ & $\mathrm{x}$ & $\mathrm{x}$ \\
\hline 66) NYSE: composite & 0 & 0 & 0 & 0 & 0 & 0 & 0 & 0 & 1 \\
\hline 67$)$ SP 500 composite & 0 & 0 & 0 & 0 & 0 & 0 & 0 & $\mathrm{x}$ & $\mathrm{x}$ \\
\hline 68) SP 500 industrials & 0 & 0 & 0 & 0 & 0 & 0 & 0 & $\mathrm{x}$ & $\mathrm{x}$ \\
\hline 69) SP500 capital & 0 & 0 & 0 & 0 & 0 & 0 & 0 & $\mathrm{x}$ & $\mathrm{x}$ \\
\hline 70$)$ SP 500 utilities & 0 & 0 & 0 & 0 & 0 & 0 & 0 & $\mathrm{x}$ & $\mathrm{x}$ \\
\hline 71) SP500: dividend & $\mathrm{x}$ & $\mathrm{x}$ & $\mathrm{x}$ & $\mathrm{x}$ & $\mathrm{x}$ & $\mathrm{x}$ & $\mathrm{x}$ & $\mathrm{x}$ & $\mathrm{x}$ \\
\hline 72$)$ SP500: price earnings & $\mathrm{x}$ & $\mathrm{x}$ & $\mathrm{x}$ & $\mathrm{x}$ & $\mathrm{x}$ & $\mathrm{x}$ & $\mathrm{x}$ & $\mathrm{x}$ & $\mathrm{x}$ \\
\hline 73$)$ FX : Switzerland & $\mathrm{x}$ & $\mathrm{x}$ & $\mathrm{x}$ & $\mathrm{x}$ & $\mathrm{x}$ & $\mathrm{x}$ & $\mathrm{x}$ & $\mathrm{x}$ & $\mathrm{x}$ \\
\hline 74) FX : Japan & $\mathrm{x}$ & $\mathrm{x}$ & $\mathrm{x}$ & $\mathrm{x}$ & $\mathrm{x}$ & $\mathrm{x}$ & $\mathrm{x}$ & $\mathrm{x}$ & $\mathrm{x}$ \\
\hline 75) FX : U.K & $\mathrm{x}$ & $\mathrm{x}$ & $\mathrm{x}$ & $\mathrm{x}$ & $\mathrm{x}$ & $\mathrm{x}$ & $\mathrm{x}$ & $\mathrm{x}$ & $\mathrm{x}$ \\
\hline 76$)$ FX : Canada & $\mathrm{x}$ & $\mathrm{x}$ & $\mathrm{x}$ & $\mathrm{x}$ & $\mathrm{x}$ & $\mathrm{x}$ & $\mathrm{x}$ & $\mathrm{x}$ & $\mathrm{x}$ \\
\hline 77$)$ Federal funds & 0 & 0 & 0 & 0 & 0 & 0 & 0 & 1 & 0 \\
\hline 78$)$ ÜS Tbili, $3 \mathrm{~m}$. & $\mathrm{x}$ & $\mathrm{x}$ & $\mathrm{x}$ & $\mathrm{x}$ & $x$ & $\mathrm{x}$ & $\mathrm{x}$ & $\mathrm{x}$ & $\mathrm{x}$ \\
\hline 79$)$ USS Tbili, $6 \mathrm{~m}$. & $x$ & $\mathrm{x}$ & $x$ & $x$ & $x$ & $x$ & $\mathrm{x}$ & $x$ & x \\
\hline 80 ) Tbond const 1 yr. & $x$ & $\mathrm{x}$ & $x$ & $x$ & $\mathrm{x}$ & $x$ & $x$ & $x$ & x \\
\hline 81 ) Tbond const 5 yr. & $\mathrm{x}$ & $\mathrm{x}$ & $\mathrm{x}$ & $\mathrm{x}$ & $\mathrm{x}$ & $\mathrm{x}$ & $\mathrm{x}$ & $\mathrm{x}$ & $\mathrm{x}$ \\
\hline 82$)$ Tbond const $10 y \mathrm{r}$. & $x$ & $x$ & $x$ & $x$ & $\mathrm{x}$ & $x$ & $x$ & $\mathrm{x}$ & x \\
\hline 83 ) Bond yield: Moody AAA & $x$ & $\mathrm{x}$ & $x$ & $x$ & $\mathrm{x}$ & $x$ & $x$ & $\mathrm{x}$ & x \\
\hline 84) Bond yield: Moody BAA & $x$ & $\mathrm{x}$ & $x$ & $x$ & $x$ & $x$ & $x$ & $x$ & x \\
\hline 85 ) Spread 3m - fed funds & $x$ & $\mathrm{x}$ & $x$ & $x$ & $\mathrm{x}$ & $x$ & $x$ & $x$ & x \\
\hline 86 ) Spread $6 \mathrm{~m}$ - fed funds & $x$ & $x$ & $x$ & $x$ & $x$ & $x$ & $x$ & $x$ & x \\
\hline 87 ) Spread 1 y - fed funds & $\mathrm{x}$ & $\mathrm{x}$ & $\mathrm{x}$ & $\mathrm{x}$ & $\mathrm{x}$ & $\mathrm{x}$ & $\mathrm{x}$ & $\mathrm{x}$ & x \\
\hline 88 ) Spread 5 y - fed funds & $\mathrm{x}$ & $\mathrm{x}$ & $\mathrm{x}$ & $\mathrm{x}$ & $\mathrm{x}$ & $\mathrm{x}$ & $\mathrm{x}$ & $\mathrm{x}$ & x \\
\hline 89 ) Spread $10 y$ - fed funds & $x$ & $x$ & $x$ & $x$ & $x$ & $x$ & $x$ & $\mathrm{x}$ & x \\
\hline 9o ) Spread AAA - fed funds & $x$ & $\mathrm{x}$ & $x$ & $x$ & $x$ & $x$ & $\mathrm{x}$ & $x$ & x \\
\hline 91) Spread BAA - fed funds & $\mathrm{x}$ & $\mathrm{x}$ & $\mathrm{x}$ & $\mathrm{x}$ & $\mathrm{x}$ & $\mathrm{x}$ & $\mathrm{x}$ & $\mathrm{x}$ & $\mathrm{x}$ \\
\hline 92) Money stock: M1 & $\mathrm{x}$ & $\mathrm{x}$ & $\mathrm{x}$ & $\mathrm{x}$ & $\mathrm{x}$ & $\mathrm{x}$ & $\mathrm{x}$ & $\mathrm{x}$ & $\mathrm{x}$ \\
\hline 93) Money stock: M2 & $\mathrm{x}$ & $\mathrm{x}$ & $\mathrm{x}$ & $\mathrm{x}$ & $\mathrm{x}$ & $\mathrm{x}$ & $\mathrm{x}$ & $\mathrm{x}$ & $\mathrm{x}$ \\
\hline 94) Money stock: M3 & $\mathrm{x}$ & $\mathrm{x}$ & $\mathrm{x}$ & $\mathrm{x}$ & $\mathrm{x}$ & $\mathrm{x}$ & $\mathrm{x}$ & $\mathrm{x}$ & $\mathrm{x}$ \\
\hline 95$)$ Money supply-M2 1992 & $\mathrm{x}$ & $\mathrm{x}$ & $\mathrm{x}$ & $\mathrm{x}$ & $\mathrm{x}$ & $\mathrm{x}$ & $\mathrm{x}$ & $\mathrm{x}$ & $\mathrm{x}$ \\
\hline 96$)$ Monetary base & $\mathrm{x}$ & $\mathrm{x}$ & $\mathrm{x}$ & $\mathrm{x}$ & $\mathrm{x}$ & $\mathrm{x}$ & $\mathrm{x}$ & $\mathrm{x}$ & $\mathrm{x}$ \\
\hline 97) Depository inst reserves & $\mathrm{x}$ & $\mathrm{x}$ & $\mathrm{x}$ & $\mathrm{x}$ & $\mathrm{x}$ & $\mathrm{x}$ & $\mathrm{x}$ & $\mathrm{x}$ & $\mathrm{x}$ \\
\hline 98$)$ Dep. Inst. Res. Nonbor. & $\mathrm{x}$ & $\mathrm{x}$ & $\mathrm{x}$ & $\mathrm{x}$ & $\mathrm{x}$ & $\mathrm{x}$ & $\mathrm{x}$ & $\mathrm{x}$ & $\mathrm{x}$ \\
\hline 99) Comm. and indust. Loans & $\mathrm{x}$ & $\mathrm{x}$ & $\mathrm{x}$ & $\mathrm{x}$ & $\mathrm{x}$ & $\mathrm{x}$ & $\mathrm{x}$ & $\mathrm{x}$ & x \\
\hline 100) W kly rp lg com. & $\mathrm{x}$ & $\mathrm{x}$ & $\mathrm{x}$ & $\mathrm{x}$ & $\mathrm{x}$ & $\mathrm{x}$ & $\mathrm{x}$ & $\mathrm{x}$ & $\mathrm{x}$ \\
\hline 101) Cons credit outst. & $\mathrm{x}$ & $\mathrm{x}$ & $\mathrm{x}$ & $\mathrm{x}$ & $\mathrm{x}$ & $\mathrm{x}$ & $\mathrm{x}$ & $\mathrm{x}$ & $\mathrm{x}$ \\
\hline 102$)$ NAPM commodity prices & 0 & 0 & 0 & 0 & 0 & 0 & 1 & 0 & 0 \\
\hline 103) PPI: finished & $\mathrm{x}$ & 0 & 0 & 0 & 0 & 0 & $\mathrm{x}$ & $\mathrm{x}$ & 0 \\
\hline 104) PPI: finished & $\mathrm{x}$ & 0 & 0 & 0 & 0 & 0 & $\mathrm{x}$ & $\mathrm{x}$ & 0 \\
\hline 105) PPI: intermed & 0 & 0 & 0 & 0 & 0 & 0 & $\mathrm{x}$ & $\mathrm{x}$ & 0 \\
\hline 106) PPI: crude & 0 & 0 & 0 & 0 & 0 & 0 & $\mathrm{x}$ & $\mathrm{x}$ & 0 \\
\hline 107 ) Index of sensitive mat. & 0 & 0 & 0 & 0 & 0 & 0 & $\mathrm{x}$ & $\mathrm{x}$ & 0 \\
\hline 108) CPI-U: all items & 1 & 0 & 0 & 0 & 0 & 0 & 0 & 0 & 0 \\
\hline 109) CPI-U: apparel, upkeep & $\mathrm{x}$ & 0 & 0 & 0 & 0 & 0 & 0 & $\mathrm{x}$ & 0 \\
\hline 110) CPI-U: transportation & $\mathrm{x}$ & 0 & 0 & 0 & 0 & 0 & 0 & $\mathrm{x}$ & 0 \\
\hline 111$)$ CPI-U: medical care & $\mathrm{x}$ & 0 & 0 & 0 & 0 & 0 & 0 & $\mathrm{x}$ & 0 \\
\hline 112) CPI-U: commodities & $x$ & 0 & 0 & 0 & 0 & 0 & $x$ & $\mathrm{x}$ & 0 \\
\hline 113) CPII-U: durables & $x$ & 0 & 0 & 0 & 0 & 0 & 0 & $\mathrm{x}$ & 0 \\
\hline 114$)$ CPI-U: services & $x$ & 0 & 0 & 0 & 0 & 0 & 0 & $\mathrm{x}$ & 0 \\
\hline 115) CPI-Ü: less food & $\mathrm{x}$ & 0 & 0 & 0 & 0 & 0 & 0 & $\mathrm{x}$ & 0 \\
\hline 116) CPI-U: less shelter & $\mathrm{x}$ & 0 & 0 & 0 & 0 & 0 & 0 & $\mathrm{x}$ & 0 \\
\hline 117) CिI-U: less medicai & $\mathrm{x}$ & 0 & 0 & 0 & 0 & 0 & 0 & $\mathrm{x}$ & 0 \\
\hline 118) Avg hr earnings constr. & $\mathrm{x}$ & $\mathrm{x}$ & $\mathrm{x}$ & $\mathrm{x}$ & $\mathrm{x}$ & $\mathrm{x}$ & 0 & $\mathrm{x}$ & $\mathrm{x}$ \\
\hline 119 ) Avg hr earnings manuf. & $\mathrm{x}$ & $\mathrm{x}$ & $\mathrm{x}$ & $\mathrm{x}$ & $\mathrm{x}$ & $\mathrm{x}$ & 0 & $\mathrm{x}$ & $\mathrm{x}$ \\
\hline 120) Consumer expec. (Mich.) & $x$ & $\mathrm{x}$ & $x$ & $x$ & $x$ & $x$ & $x$ & $x$ & $\mathrm{x}$ \\
\hline
\end{tabular}

The factors are denoted by the symbols $\left\{\pi, u_{n}, y, c, h r s, h, p c o m, i, s\right\}$ and describe general inflation, unemployment, economic activity (growth), consumption growth, hours in production, residential investments, commodity price inflation, federal funds rate and stock markets returns respectively. $\mathrm{x}$ denotes a free factor loading that is estimated. Shading areas cover loadings that are fixed with unbiasedness restrictions. 
Table 2: Model Performance.

\begin{tabular}{lcccccc}
\hline \hline & $R^{2}$ & $A I C$ & $B I C$ & $I C_{p 2}^{*}$ & $\log$ Lik & $p$-value for LR test \\
\hline Exactly Identified Model & 57.0 & 1.449 & 1.684 & -0.565 & -42821 & - \\
& & & & & & - \\
Our (Restricted) Model & 53.2 & 1.518 & 1.685 & -0.475 & -45413 & 0.0002 \\
\hline \hline
\end{tabular}

$R^{2}$ is a simple average of the R-squared of the 120 series; $A I C$ denotes Akaike Information Criterion; $B I C$ is Bayesian Information Criterion; $I C_{p 2}^{*}$ is a modified version of the Bai \& $\mathrm{Ng}(2002) I C_{p 2}$ information criterion; and $L o g$ Lik is the Log-Likelihood value. 
Table 3: Estimated factor loadings.

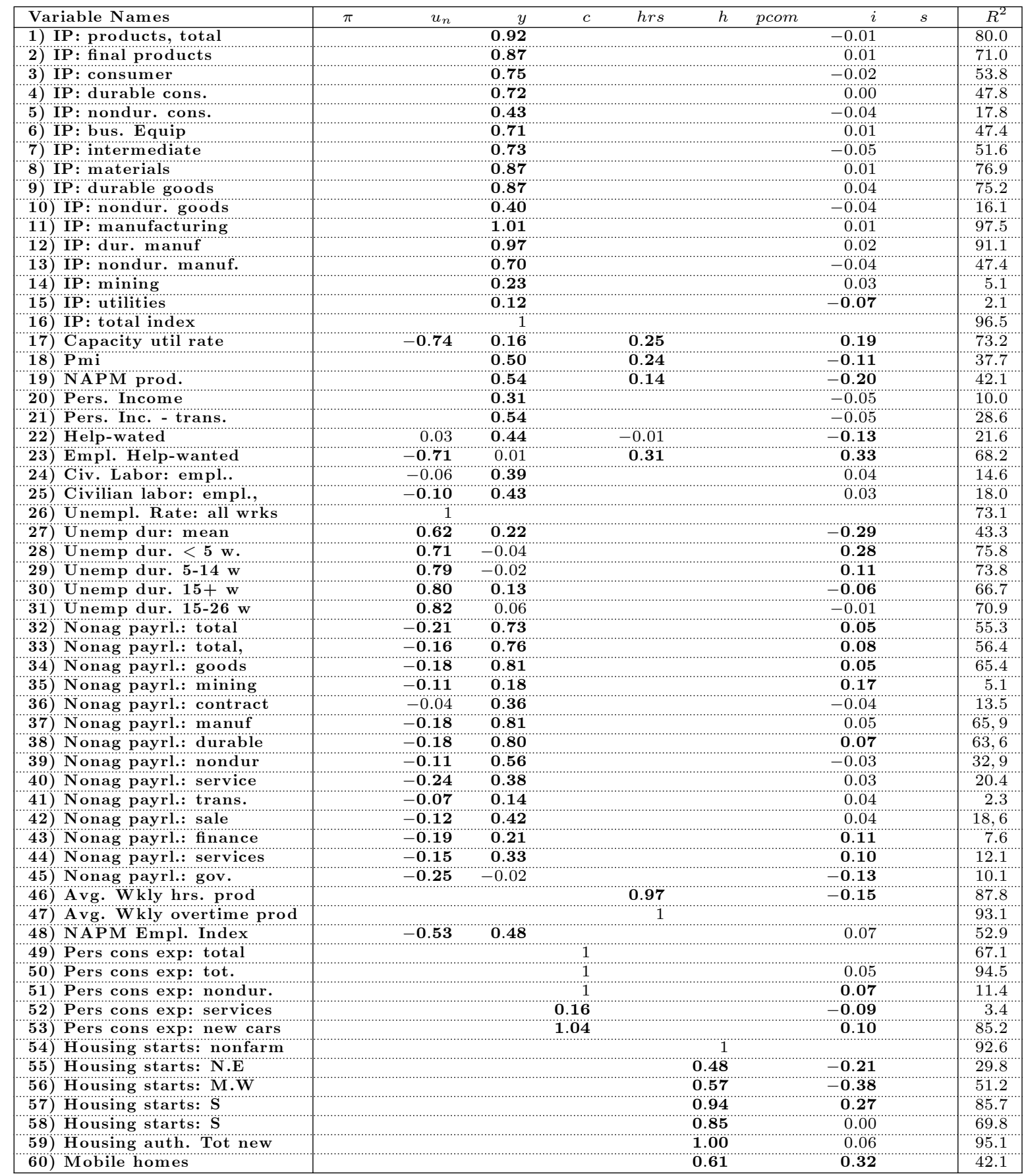

The factors are denoted by the symbols $\left\{\pi, u_{n}, y, c, h r s, h, p c o m, i, s\right\}$ and describe general inflation, unemployment, economic activity (growth), consumption growth, hours in production, residential investments, commodity price inflation, federal funds rate and stock markets returns respectively. $R^{2}$ denotes R-squared. Coefficients in bold are statistically significant at the $5 \%$ level (the standard errors are two-sided finite difference approximations of the gradient of the likelihood function. 
Table 3 continued

\begin{tabular}{|c|c|c|c|c|c|c|c|c|c|c|}
\hline Variable Names & $\pi$ & $u_{n}$ & $y$ & $c$ & hrs & $h$ & pcom & $i$ & $s$ & $R^{2}$ \\
\hline 61) NAPM inventories & 0.06 & -0.39 & 0.08 & 0.00 & 0.01 & 0.27 & 0.16 & 0.04 & -0.05 & 45.6 \\
\hline 62$)$ NAPM new orders & -0.09 & 0.08 & 0.39 & -0.01 & 0.07 & 0.26 & 0.30 & -0.29 & 0.00 & 60.8 \\
\hline 63) NAPM vendor deliv. & 0.04 & -0.29 & 0.15 & -0.01 & 0.26 & 0.21 & 0.15 & 0.14 & -0.09 & 46.2 \\
\hline 64$)$ New orders: cons goods & 0.00 & 0.08 & 0.50 & 0.13 & -0.06 & 0.00 & -0.01 & -0.07 & 0.07 & 29.3 \\
\hline 65$)$ New orders: nondefense & 0.04 & 0.01 & 0.06 & 0.12 & 0.03 & 0.03 & 0.03 & -0.05 & 0.00 & 2.7 \\
\hline 66) NYSE: composite & & & & & & & & & 1 & 97.6 \\
\hline 67) SP500 composite & & & & & & & & $0.00^{\circ}$ & 1.01 & 100.0 \\
\hline 68) SP500 industrials & & & & & & & & 0.00 & 1.00 & 98.7 \\
\hline 69 SPP500 capital & & & & & & & & -0.02 & 0.92 & 83.0 \\
\hline 70$)$ SP500 utilities & & & & & & & & 0.01 & 0.61 & 36.4 \\
\hline 71 ) SP5o0: dividend & 0.08 & 0.30 & -0.02 & 0.00 & -0.49 & -0.09 & 0.32 & 0.31 & -0.03 & 80.7 \\
\hline 72$)$ SP500: price earnings & -0.06 & -0.17 & 0.01 & -0.01 & 0.48 & 0.05 & -0.30 & -0.37 & 0.00 & 69.8 \\
\hline 73$)$ FX : Switzerland & -0.08 & -0.02 & 0.17 & 0.08 & 0.06 & -0.19 & 0.08 & 0.14 & 0.07 & 6.0 \\
\hline 74$)^{2}$ FX: Japan & -0.12 & -0.13 & 0.09 & 0.00 & 0.01 & -0.18 & 0.06 & 0.19 & -0.04 & 6.1 \\
\hline 75$)$ FX : U.K & 0.10 & -0.03 & -0.16 & -0.05 & 0.03 & 0.13 & -0.01 & -0.15 & 0.01 & 4.7 \\
\hline 76$) \mathrm{FX}$ : Canada & -0.01 & 0.07 & 0.13 & 0.04 & -0.01 & -0.04 & 0.01 & -0.02 & -0.24 & 6.9 \\
\hline 77 ) Federal funds & & & & & & & & 1 & & 100.0 \\
\hline 78) USS Toill. 3m. & -0.06 & 0.12 & 0.02 & -0.01 & 0.03 & -0.03 & 0.12 & 0.96 & 0.01 & 98,2 \\
\hline 79$)$ US THbill. $6 \mathrm{~m}$. & -0.08 & 0.16 & 0.01 & -0.01 & 0.03 & -0.03 & 0.17 & 0.94 & 0.00 & 98.7 \\
\hline 80 ) Tbond const 1 yr. & -0.12 & 0.24 & 0.01 & -0.02 & 0.04 & -0.04 & 0.23 & 0.91 & 0.00 & 99.0 \\
\hline 81) Tbond const 5 yr. & -0.17 & 0.54 & -0.02 & -0.02 & 0.10 & -0.02 & 0.28 & 0.76 & -0.01 & 100.0 \\
\hline 82$)$ Tbond const $10 y \mathrm{r}$. & -0.14 & 0.62 & -0.02 & -0.02 & 0.13 & 0.00 & 0.26 & 0.69 & -0.01 & 99.7 \\
\hline 83 ) Bond yield: Moody AAA & -0.06 & 0.65 & -0.05 & -0.02 & 0.19 & 0.07 & 0.12 & 0.65 & -0.02 & 100.0 \\
\hline 84) Bond yield: Moody BAA & -0.06 & 0.65 & -0.05 & -0.01 & 0.11 & 0.08 & 0.10 & 0.64 & 0.00 & 99.7 \\
\hline 85 ) Spread $3 \mathrm{~m}$ - fed funds & -0.21 & 0.38 & 0.07 & -0.03 & 0.10 & -0.09 & 0.39 & -0.88 & 0.04 & 80.5 \\
\hline 86 Spread $6 \mathrm{~m}$ - fed funds & -0.24 & 0.47 & 0.04 & -0.03 & 0.08 & -0.09 & 0.50 & -0.92 & 0.01 & 88.7 \\
\hline 87 Spread $1 y$ - fed funds & -0.38 & 0.75 & 0.02 & -0.05 & 0.11 & -0.12 & 0.70 & -0.79 & 0.01 & 90.4 \\
\hline 88) Spread $5 y$ - fed funds & -0.29 & 0.93 & -0.03 & -0.04 & 0.18 & -0.04 & 0.49 & -0.85 & -0.01 & 100.0 \\
\hline 89$)$ Spread $10 y$ - fed funds & -0.21 & 0.93 & -0.03 & -0.03 & 0.19 & 0.00 & 0.40 & -0.87 & -0.01 & 99.3 \\
\hline 90) Spread AAA - fed funds & -0.09 & 0.91 & -0.07 & -0.02 & 0.26 & 0.10 & 0.17 & -0.85 & -0.02 & 100.0 \\
\hline 91) Spread BAA - fed funds & -0.09 & 1.00 & -0.08 & -0.02 & 0.17 & 0.12 & 0.15 & -0.72 & -0.01 & 99.3 \\
\hline 92) Money stock: M1 & 0.17 & 0.31 & -0.05 & 0.08 & -0.21 & 0.29 & -0.08 & -0.13 & 0.05 & 23.0 \\
\hline 93$)$ Money stock: M2 & 0.02 & 0.03 & 0.00 & 0.03 & -0.59 & 0.51 & -0.14 & 0.02 & 0.04 & 39.7 \\
\hline 94$)$ Money stock: M3 & 0.03 & -0.12 & -0.04 & 0.06 & -0.44 & 0.59 & -0.07 & 0.18 & 0.06 & 36.6 \\
\hline 95 ) Money supply-M2 1992 & -0.53 & -0.01 & 0.02 & 0.03 & -0.44 & 0.40 & -0.13 & 0.00 & 0.04 & 53.7 \\
\hline 96$)$ Monetary base & 0.25 & 0.25 & -0.04 & 0.01 & 0.14 & 0.23 & -0.13 & -0.05 & 0.02 & 15.3 \\
\hline 97$)$ Depository inst reserves & 0.04 & 0.16 & 0.02 & -0.06 & -0.21 & 0.17 & -0.09 & -0.05 & 0.00 & 9.7 \\
\hline 98) Dep. Inst. Res. Nonbor. & 0.10 & 0.07 & -0.15 & -0.01 & -0.16 & 0.07 & -0.18 & -0.09 & 0.06 & 11.5 \\
\hline 99) Comm. and indust. Loans & -0.24 & -0.22 & 0.03 & 0.03 & 0.19 & -0.08 & 0.23 & 0.31 & 0.02 & 20.5 \\
\hline 100) Wkly rp lg com. & -0.13 & 0.02 & 0.03 & -0.02 & 0.34 & -0.06 & 0.22 & 0.23 & 0.10 & 15.9 \\
\hline 101) Cons credit outst. & -0.21 & -0.06 & 0.02 & 0.05 & -0.09 & 0.36 & 0.29 & 0.08 & -0.03 & 30.1 \\
\hline 102$)$ NAPM commodity prices & & & & & & & 1 & & & 39.0 \\
\hline 103) PPI: finished & 0.79 & & & & & & 0.03 & -0.12 & & 52.8 \\
\hline 104$)$ PPI: finished & 0.76 & & & & & & 0.05 & -0.17 & & 47.4 \\
\hline 105) PPI: intermed & & & & & & & 0.28 & 0.23 & & 18.6 \\
\hline 106) PPII: crude & & & & & & & 0.20 & -0.01 & & 5.2 \\
\hline 107$)$ Index of sensitive mat. & & & & & & & 0.33 & -0.14 & & 13.8 \\
\hline 108) CPI-Ü: ali items & 1 & & & & & & & & & 95.7 \\
\hline 109) CPI-UU: apparel. upkeep & 0.44 & & & & & & & -0.02 & & 17.7 \\
\hline 110) CPI-UU: transportation & 0.85 & & & & & & & -0.20 & & 53.3 \\
\hline 111) CPI-UU: medical care & 0.23 & & & & & & & 0.41 & & 33.2 \\
\hline 1112) CP I-UU: commodities & 1.02 & & & & & & 0.06 & -0.21 & & 86.1 \\
\hline 113 ) CPII-UU: durables & 0.58 & & & & & & & 0.11 & & 40.5 \\
\hline 114$)$ CPII-UT: services & 0.51 & & & & & & & 0.33 & & 55.8 \\
\hline 115) CPI-U: less food & 0.85 & & & & & & & 0.10 & & 79.8 \\
\hline 116) CPI-U: less shelter & 1.01 & & & & & & & -0.09 & & 88.3 \\
\hline 117) CPI-Ü: less medical & 1.00 & & & & & & & -0.02 & & 93.7 \\
\hline 118) Avg hr earnings constr. & 0.10 & -0.15 & -0.13 & 0.07 & -0.12 & 0.04 & & 0.07 & -0.03 & 6.8 \\
\hline 119) Avg hr earnings manuf. & 0.30 & -0.04 & 0.31 & -0.03 & -0.21 & 0.03 & & 0.11 & 0.00 & 23.5 \\
\hline 120) Consumer expec. (Mich.) & -0.67 & -0.23 & 0.12 & 0.00 & 0.11 & 0.03 & 0.23 & -0.12 & 0.02 & 67.7 \\
\hline
\end{tabular}

The factors are denoted by the symbols $\left\{\pi, u_{n}, y, c, h r s, h, p c o m, i, s\right\}$ and describe general inflation, unemployment, economic activity (growth), consumption growth, hours in production, residential investments, commodity price inflation, federal funds rate and stock markets returns respectively. $R^{2}$ denotes R-squared. Coefficients in bold are statistically significant at the $5 \%$ level (the standard errors are two-sided finite difference approximations of the gradient of the likelihood function. 
Table 4: Forecast error variance due to monetary policy shocks.

\begin{tabular}{|c|c|c|c|c|c|c|c|c|c|c|c|}
\hline Average (all variables) & $\pi$ & $u_{n}$ & $y$ & $c$ & hrs & $h$ & pcom & $i$ & $s$ & total & Idio. \\
\hline 6 month & 0.03 & 0.05 & 0.06 & 0.03 & 0.07 & 0.04 & 0.04 & 0.05 & 0.04 & 0.41 & 0.59 \\
\hline 12 month & 0.04 & 0.05 & 0.06 & 0.03 & 0.09 & 0.06 & 0.04 & 0.05 & 0.05 & 0.46 & 0.54 \\
\hline 24 month & 0.04 & 0.05 & 0.06 & 0.03 & 0.10 & 0.08 & 0.03 & 0.05 & 0.06 & 0.50 & 0.50 \\
\hline 60 month & 0.06 & 0.05 & 0.06 & 0.03 & 0.10 & 0.11 & 0.03 & 0.04 & 0.06 & 0.53 & 0.47 \\
\hline 12 month horizon & $\pi$ & $u_{n}$ & $y$ & $c$ & hrs & $h$ & pcom & $i$ & $s$ & total & Idio. \\
\hline 77) Federal funds rate & 0.02 & 0.06 & 0.06 & 0.03 & 0.41 & 0.15 & 0.04 & 0.16 & 0.08 & 1.00 & 0.00 \\
\hline 16 ) IP: totalindex & 0.05 & 0.21 & 0.32 & 0.01 & 0.12 & 0.09 & 0.02 & 0.09 & 0.05 & 0.95 & 0.05 \\
\hline 108) CPI-U: all items & 0.37 & 0.03 & 0.03 & 0.03 & 0.24 & 0.11 & 0.04 & 0.03 & 0.01 & 0.91 & 0.09 \\
\hline 78) US Tbill, 3m. & 0.03 & 0.03 & 0.04 & 0.02 & 0.38 & 0.15 & 0.09 & 0.12 & 0.08 & 0.94 & 0.06 \\
\hline Tbond const $5 y r$. & 0.06 & 0.02 & 0.00 & 0.01 & 0.31 & 0.12 & 0.34 & 0.08 & 0.04 & 1.00 & 0.00 \\
\hline 96) Monetary base & 0.02 & 0.01 & 0.01 & 0.00 & 0.00 & 0.00 & 0.01 & 0.00 & 0.00 & 0.06 & 0.94 \\
\hline 93) Money stock: M2 & 0.02 & 0.01 & 0.01 & 0.00 & 0.12 & 0.03 & 0.04 & 0.01 & 0.03 & 0.25 & 0.75 \\
\hline 74) FX:Japan & 0.01 & 0.00 & 0.01 & 0.00 & 0.01 & 0.00 & 0.01 & 0.00 & 0.01 & 0.05 & 0.95 \\
\hline 102) NAPM commodity prices & 0.02 & 0.01 & 0.01 & 0.01 & 0.04 & 0.10 & 0.28 & 0.05 & 0.02 & 0.54 & 0.46 \\
\hline 17) Capacity util rate & 0.02 & 0.07 & 0.04 & 0.01 & 0.10 & 0.09 & 0.00 & 0.10 & 0.10 & 0.52 & 0.48 \\
\hline 49) Pers cons exp: total & 0.02 & 0.01 & 0.02 & 0.57 & 0.01 & 0.02 & 0.01 & 0.02 & 0.00 & 0.69 & 0.31 \\
\hline 50) Pers cons exp: tot. dur & 0.02 & 0.02 & 0.02 & 0.73 & 0.01 & 0.02 & 0.02 & 0.02 & 0.01 & 0.87 & 0.13 \\
\hline 51) Pers cons exp: nondur. & 0.01 & 0.01 & 0.01 & 0.35 & 0.01 & 0.01 & 0.01 & 0.01 & 0.00 & 0.41 & 0.59 \\
\hline Unempl.Rate: all wrks & 0.01 & 0.15 & 0.04 & 0.01 & 0.04 & 0.06 & 0.00 & 0.09 & 0.06 & 0.45 & 0.55 \\
\hline 48) NAPM Empl. Index & 0.02 & 0.06 & 0.09 & 0.00 & 0.06 & 0.06 & 0.00 & 0.05 & 0.05 & 0.40 & 0.60 \\
\hline 118) Avg hr earnings constr. & 0.00 & 0.01 & 0.01 & 0.00 & 0.00 & 0.00 & 0.00 & 0.00 & 0.00 & 0.03 & 0.97 \\
\hline 54) Housing starts: nonfarm & 0.01 & 0.01 & 0.07 & 0.01 & 0.24 & 0.39 & 0.03 & 0.10 & 0.01 & 0.86 & 0.14 \\
\hline 62) NAPM new orders & 0.02 & 0.06 & 0.09 & 0.00 & 0.08 & 0.08 & 0.04 & 0.11 & 0.02 & 0.50 & 0.50 \\
\hline 71) SP500: dividend yield & 0.02 & 0.00 & 0.02 & 0.02 & 0.06 & 0.02 & 0.21 & 0.04 & 0.01 & 0.40 & 0.60 \\
\hline 120) Consumer expec. (Mich.) & 0.20 & 0.01 & 0.03 & 0.01 & 0.07 & 0.03 & 0.02 & 0.03 & 0.03 & 0.43 & 0.57 \\
\hline 60 month horizon & $\pi$ & $u_{n}$ & $y$ & $c$ & hrs & $h$ & pcom & $i$ & $s$ & total & Idio. \\
\hline 77) Federal funds rate & 0.10 & 0.04 & 0.04 & 0.05 & 0.19 & 0.38 & 0.06 & 0.07 & 0.07 & 1.00 & 0.00 \\
\hline 16 ) IP: totalindex & 0.05 & 0.19 & 0.29 & 0.01 & 0.14 & 0.12 & 0.01 & 0.09 & 0.07 & 0.96 & 0.04 \\
\hline 108) CPI-U: all items & 0.35 & 0.04 & 0.04 & 0.04 & 0.19 & 0.19 & 0.03 & 0.05 & 0.03 & 0.94 & 0.06 \\
\hline 78) US Tbill, 3m. & 0.11 & 0.03 & 0.03 & 0.05 & 0.19 & 0.37 & 0.08 & 0.05 & 0.06 & 0.98 & 0.02 \\
\hline 81) Tbond const 5yr. & 0.16 & 0.02 & 0.02 & 0.05 & 0.19 & 0.37 & 0.14 & 0.03 & 0.03 & 1.00 & 0.00 \\
\hline Monetary base & 0.02 & 0.02 & 0.01 & 0.00 & 0.01 & 0.01 & 0.02 & 0.00 & 0.01 & 0.10 & 0.90 \\
\hline 93) Money stock: M2 & 0.02 & 0.01 & 0.01 & 0.01 & 0.13 & 0.06 & 0.05 & 0.02 & 0.05 & 0.35 & 0.65 \\
\hline 74) FX:Japan & 0.01 & 0.00 & 0.01 & 0.00 & 0.02 & 0.00 & 0.01 & 0.01 & 0.01 & 0.07 & 0.93 \\
\hline 102) NAPM commodity prices & 0.03 & 0.01 & 0.01 & 0.02 & 0.06 & 0.12 & 0.26 & 0.05 & 0.04 & 0.61 & 0.39 \\
\hline 17) Capacity util rate & 0.05 & 0.05 & 0.04 & 0.02 & 0.15 & 0.19 & 0.02 & 0.11 & 0.08 & 0.71 & 0.29 \\
\hline 49) Pers cons exp: total & 0.02 & 0.02 & 0.02 & 0.56 & 0.02 & 0.02 & 0.01 & 0.02 & 0.01 & 0.69 & 0.31 \\
\hline 50) Pers cons exp: tot. dur & 0.02 & 0.02 & 0.02 & 0.72 & 0.02 & 0.03 & 0.02 & 0.03 & 0.01 & 0.87 & 0.13 \\
\hline Pers cons exp: nondur. & 0.01 & 0.01 & 0.01 & 0.35 & 0.01 & 0.01 & 0.01 & 0.01 & 0.00 & 0.42 & 0.58 \\
\hline Unempl.Rate: all wrks & 0.05 & 0.09 & 0.03 & 0.02 & 0.17 & 0.19 & 0.01 & 0.10 & 0.06 & 0.72 & 0.28 \\
\hline 48) NAPM Empl. Index & 0.03 & 0.05 & 0.08 & 0.01 & 0.11 & 0.10 & 0.01 & 0.05 & 0.05 & 0.50 & 0.50 \\
\hline 118) Avg hr earnings constr. & 0.01 & 0.01 & 0.01 & 0.01 & 0.01 & 0.02 & 0.00 & 0.01 & 0.00 & 0.07 & 0.93 \\
\hline 54) Housing starts: nonfarm & 0.02 & 0.05 & 0.07 & 0.01 & 0.37 & 0.25 & 0.02 & 0.08 & 0.04 & 0.93 & 0.07 \\
\hline 62) NAPM new orders & 0.03 & 0.06 & 0.08 & 0.01 & 0.16 & 0.11 & 0.04 & 0.10 & 0.05 & 0.63 & 0.37 \\
\hline 71) SP500: dividend yield & 0.16 & 0.01 & 0.02 & 0.06 & 0.08 & 0.22 & 0.19 & 0.03 & 0.01 & 0.78 & 0.22 \\
\hline 120) Consumer expec. (Mich.) & 0.22 & 0.02 & 0.03 & 0.03 & 0.11 & 0.17 & 0.02 & 0.03 & 0.02 & 0.66 & 0.34 \\
\hline
\end{tabular}

The upper panel illustrates the total fractions that the eight factors can explain of the forecast error variance on average for the panel at varying horizon. "Idio." means idiosyncratic variance. The factors are denoted by the symbols $\left\{\pi, u_{n}, y, c, h r s, h, p c o m, i, s\right\}$ and describes general inflation, unemployment, economic activity (growth), consumption growth, hours in production, residential investments, commodity price inflation, federal funds rate and stock markets returns respectively. The middle and lower panel shows the 12 month ahead and $60 \mathrm{month}$ ahead forecast error variance decomposition for key macroeconomic variables. 


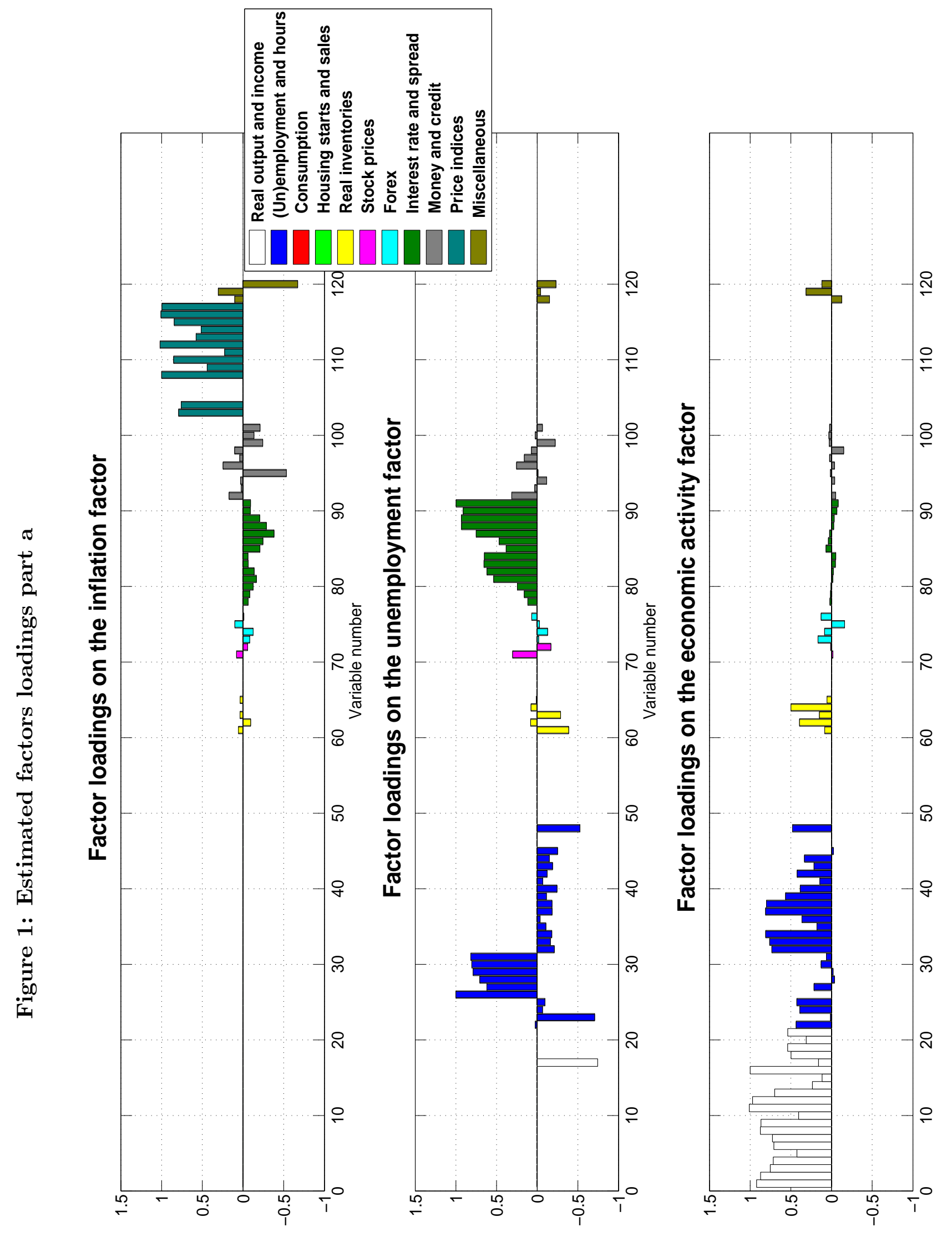




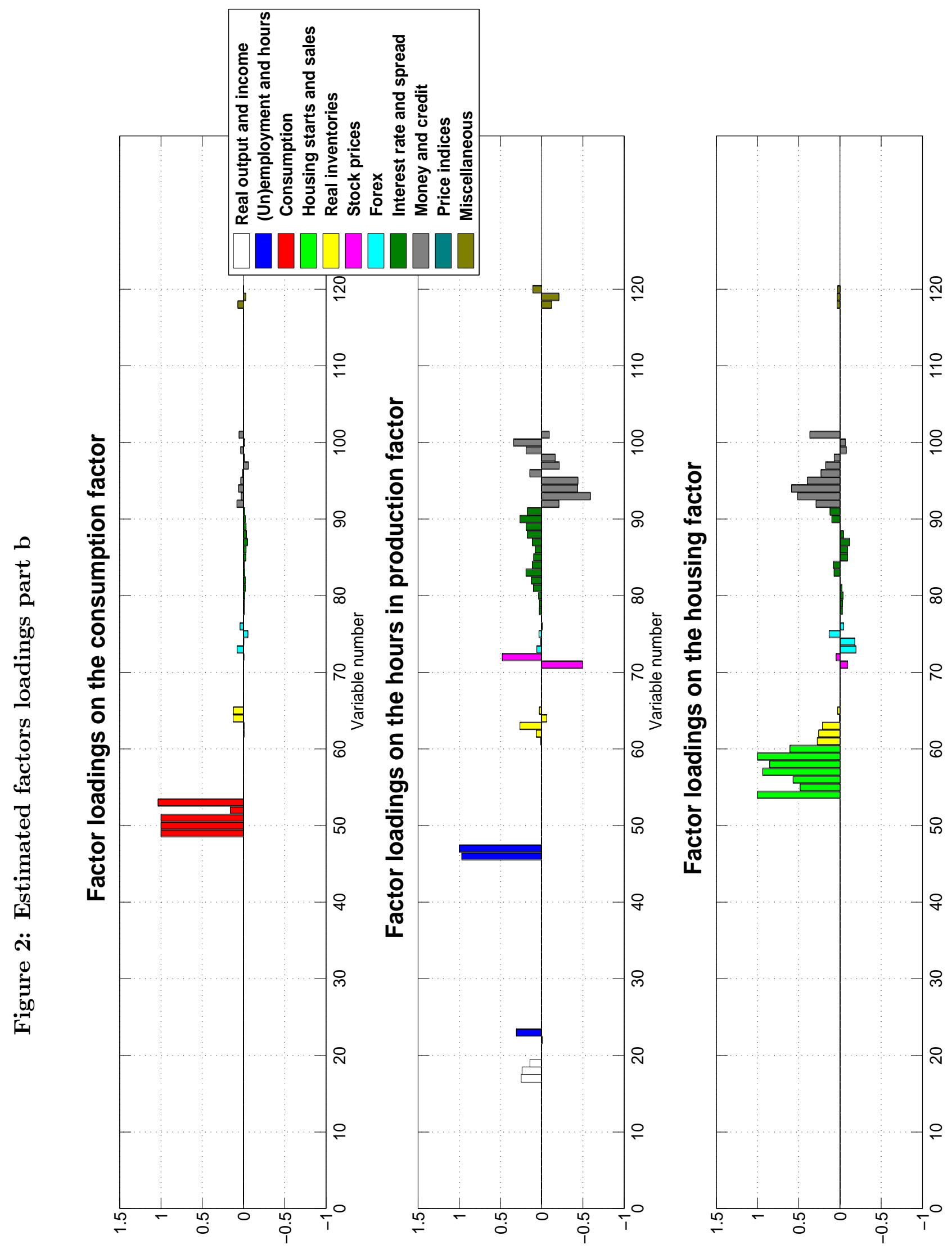




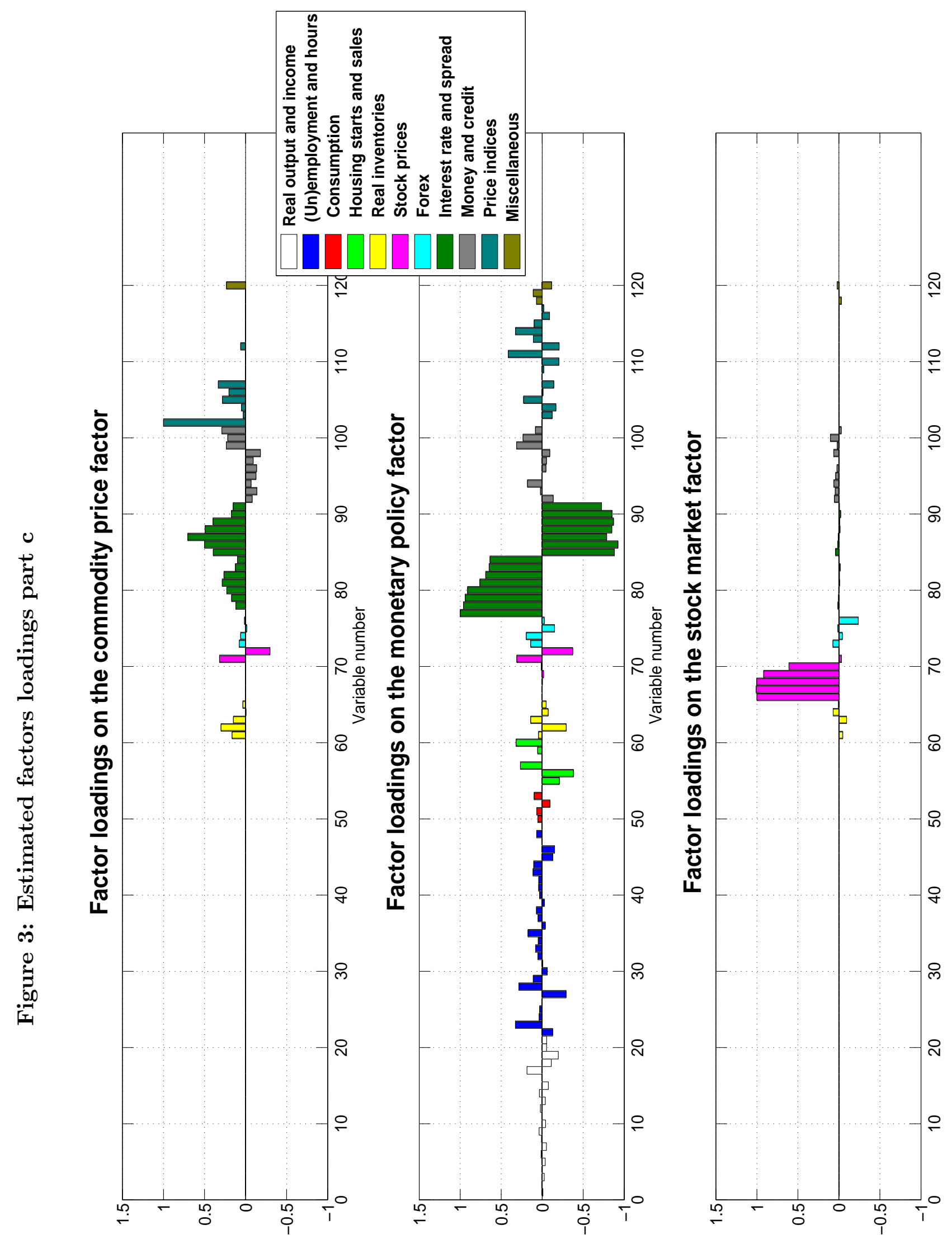



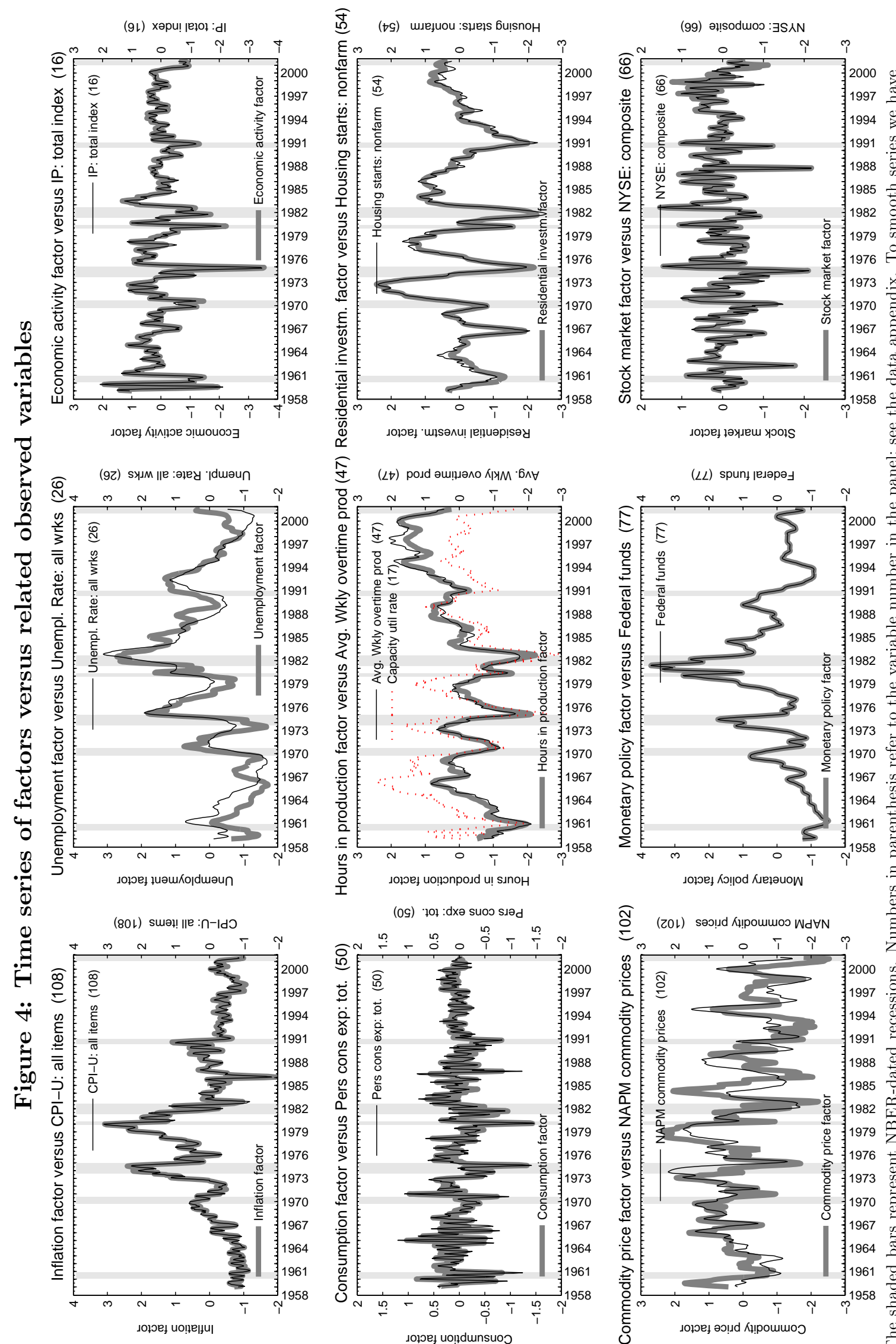

(09) '아 :dxə suoo s.əd
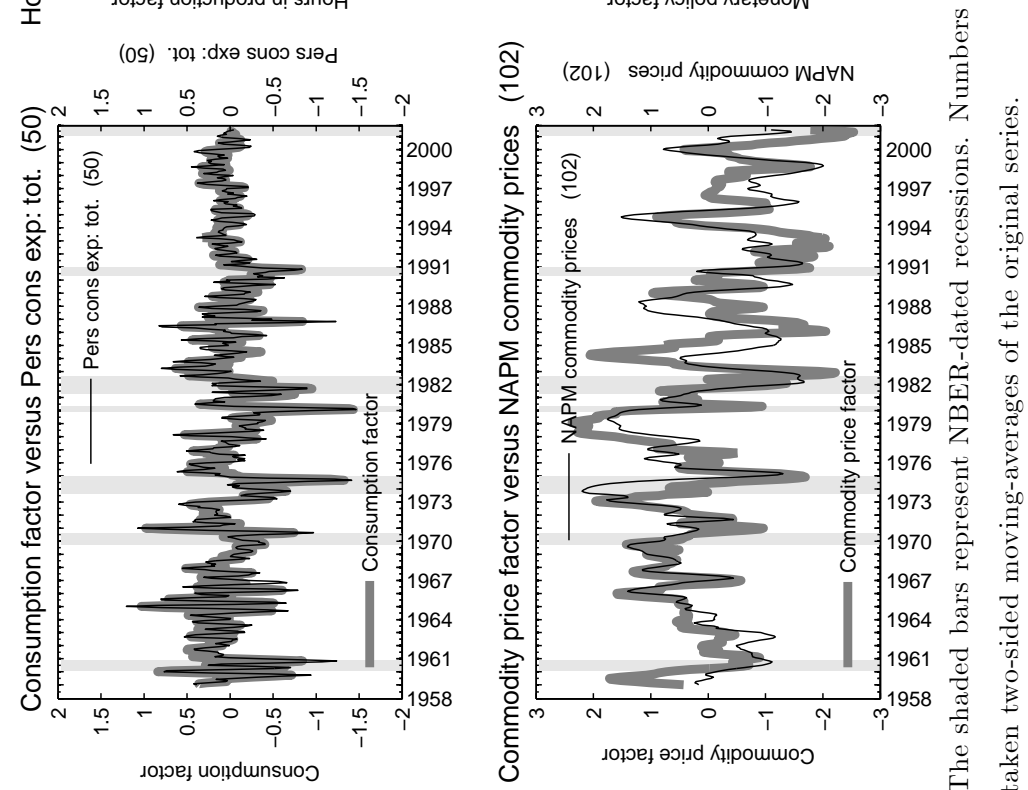
Figure 5: Impulse responses to a 25 basis point monetary policy shock.
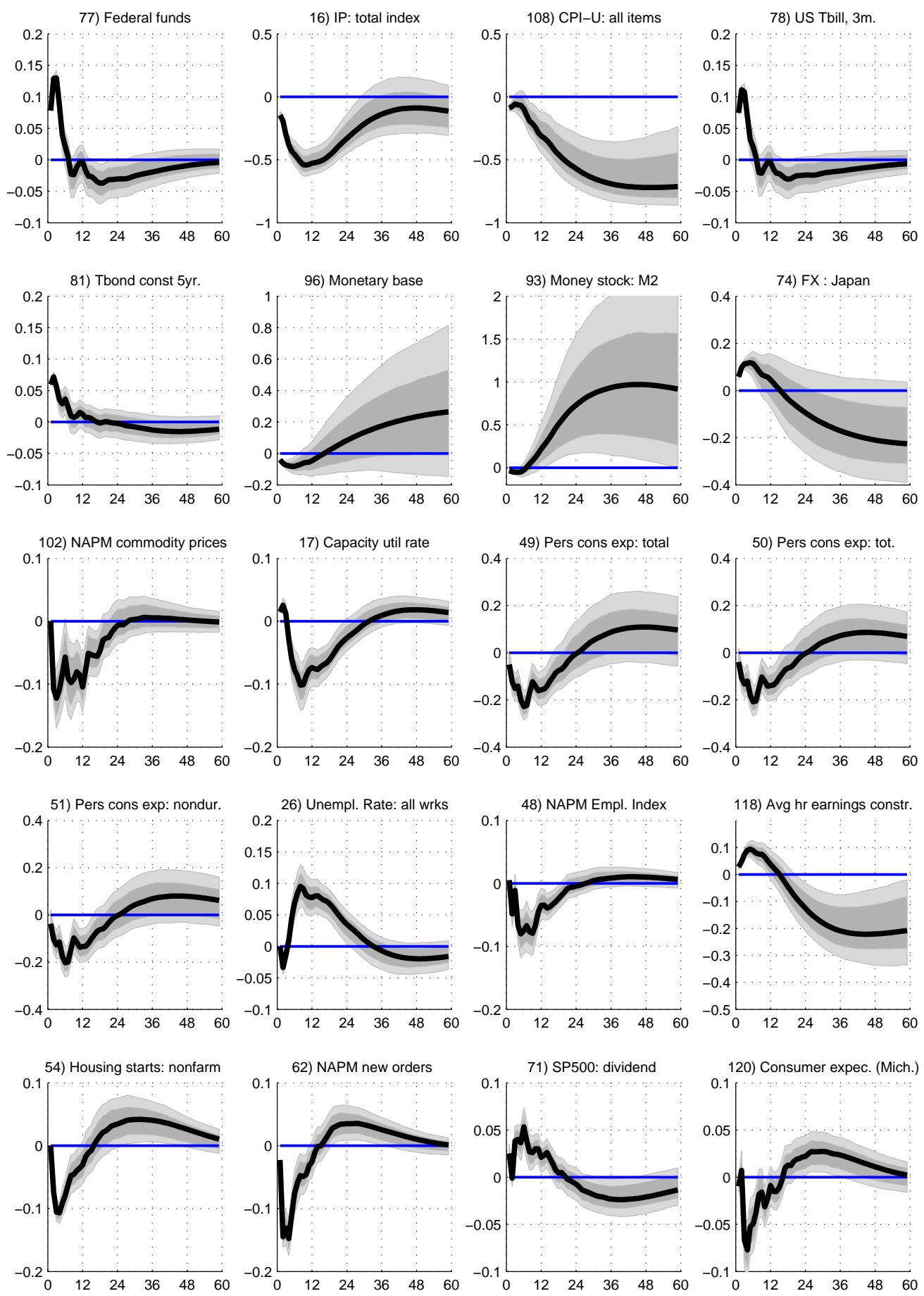

The figure illustrates the impulse responses in standard deviations of key macroeconomic variables following a 25 basis point monetary policy shock. The horizontal axis denotes the forecast horizon in months. Confidence intervals are represented by dark bands (68 percent) and light bands (90 percent) 
Figure 6: Forecast error variance due to monetary policy shocks.
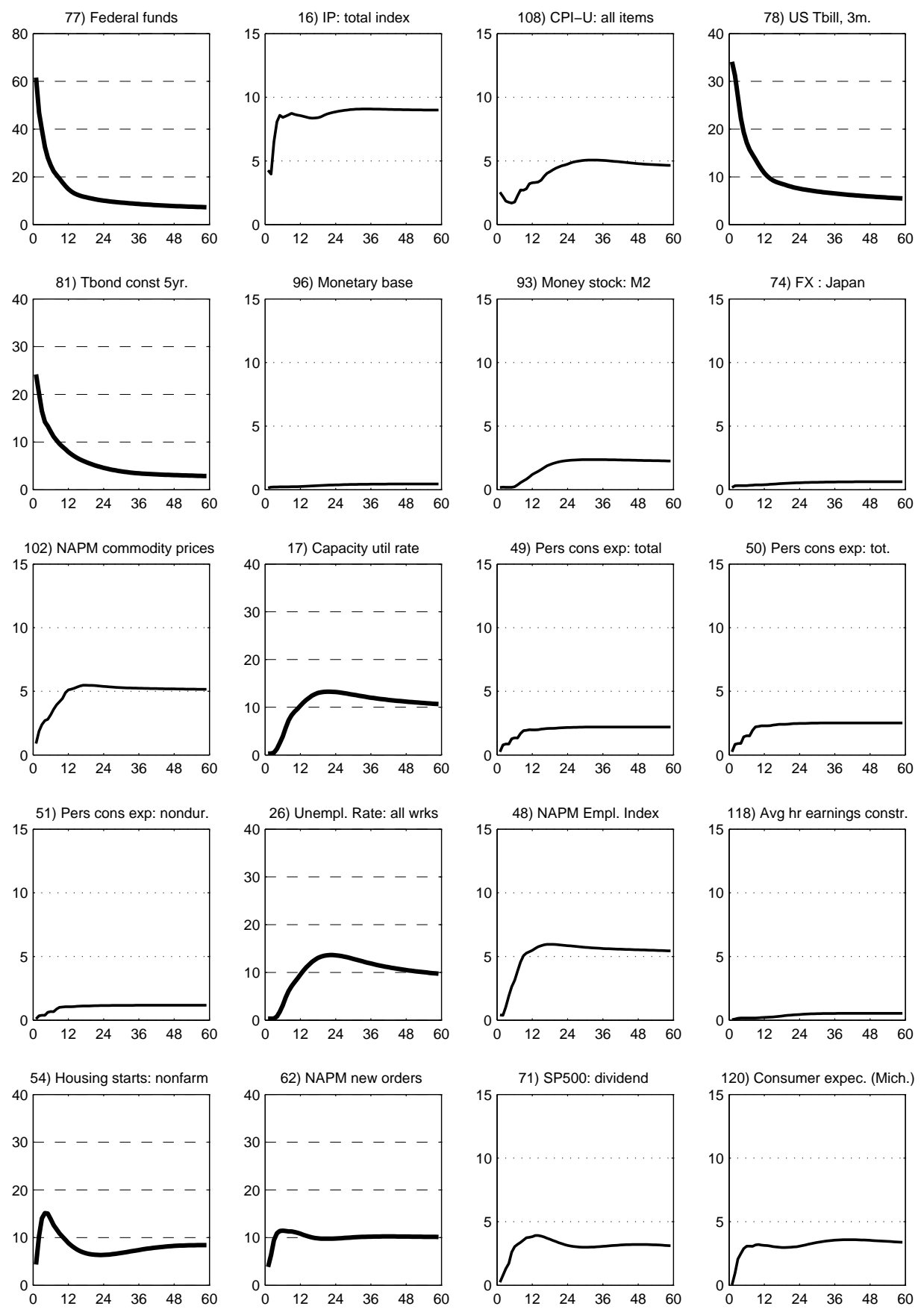

The figure plots the contribution of the monetary policy shock to the forecast error variance decomposition of key macroeconomic variables along the foreast horizon (the horizontal axis). Dashed gridlines indicate a larger scale compared to the dotted grid lines. 


\section{Working Papers from Finance Research Group}

F-2009-06 Lasse Bork, Hans Dewachter \& Romain Houssa: Identification of Macroeconomic Factors in Large Panels.

F-2009-05 Rama Cont \& Thomas Kokholm: A Consistent Pricing Model for Index Options and Volatility Derivatives.

F-2009-04 Stefan Hirth \& Marliese Uhrig-Homburg: Investment Timing, Liquidity, and Agency Costs of Debt.

F-2009-03 Lasse Bork: Estimating US Monetary Policy Shocks Using a FactorAugmented Vector Autoregression: An EM Algorithm Approach.

F-2009-02 Leonidas Tsiaras: The Forecast Performance of Competing Implied Volatility Measures: The Case of Individual Stocks.

F-2009-01 Thomas Kokholm \& Elisa Nicolato: Sato Processes in Default Modeling.

F-2008-07 Esben Høg, Per Frederiksen \& Daniel Schiemert: On the Generalized Brownian Motion and its Applications in Finance.

F-2008-06 Esben Høg: Volatility and realized quadratic variation of differenced returns. A wavelet method approach.

F-2008-05 Peter Løchte Jørgensen \& Domenico De Giovanni: Time Charters with Purchase Options in Shipping: Valuation and Risk Management.

F-2008-04 Stig V. Møller: Habit persistence: Explaining cross-sectional variation in returns and time-varying expected returns.

F-2008-03 Thomas Poulsen: Private benefits in corporate control transactions.

F-2008-02 Thomas Poulsen: Investment decisions with benefits of control.

F-2008-01 Thomas Kokholm: Pricing of Traffic Light Options and other Correlation Derivatives.

F-2007-03 Domenico De Giovanni: Lapse Rate Modeling: A Rational Expectation Approach.

F-2007-02 Andrea Consiglio \& Domenico De Giovanni: Pricing the Option to Surrender in Incomplete Markets.

F-2006-09 Peter Løchte Jørgensen: Lognormal Approximation of Complex Pathdependent Pension Scheme Payoffs.

F-2006-08 Peter Løchte Jørgensen: Traffic Light Options. 
F-2006-07 David C. Porter, Carsten Tanggaard, Daniel G. Weaver \& Wei Yu: Dispersed Trading and the Prevention of Market Failure: The Case of the Copenhagen Stock Exhange.

F-2006-06 Amber Anand, Carsten Tanggaard \& Daniel G. Weaver: Paying for Market Quality.

F-2006-05 Anne-Sofie Reng Rasmussen: How well do financial and macroeconomic variables predict stock returns: Time-series and cross-sectional evidence.

F-2006-04 Anne-Sofie Reng Rasmussen: Improving the asset pricing ability of the Consumption-Capital Asset Pricing Model.

F-2006-03 Jan Bartholdy, Dennis Olson \& Paula Peare: Conducting event studies on a small stock exchange.

F-2006-02 Jan Bartholdy \& Cesário Mateus: Debt and Taxes: Evidence from bankfinanced unlisted firms.

F-2006-01 Esben P. Høg \& Per H. Frederiksen: The Fractional Ornstein-Uhlenbeck Process: Term Structure Theory and Application.

F-2005-05 Charlotte Christiansen \& Angelo Ranaldo: Realized bond-stock correlation: macroeconomic announcement effects.

F-2005-04 Søren Willemann: GSE funding advantages and mortgagor benefits: Answers from asset pricing.

F-2005-03 Charlotte Christiansen: Level-ARCH short rate models with regime switching: Bivariate modeling of US and European short rates.

F-2005-02 Charlotte Christiansen, Juanna Schröter Joensen and Jesper Rangvid: Do more economists hold stocks?

F-2005-01 Michael Christensen: Danish mutual fund performance - selectivity, market timing and persistence.

F-2004-01 Charlotte Christiansen: Decomposing European bond and equity volatility. 
ISBN 9788778824332

Department of Business Studies

Aarhus School of Business

Aarhus University

Fuglesangs Allé 4

DK-8210 Aarhus V - Denmark

Tel. +4589486688

Fax +4586150188

www.asb.dk 